\title{
The Lonesome Sailing Ship Reflections on the Rock-Carvings of Sweden and Their Interpreters
}

\author{
Katherine Hauptman Wahlgren
}

\begin{abstract}
The study of rock-carvings has developed into a separate field of archaeology, often outside the general discourse. The number of works on the subject does not reflect the wide range of interpretations that could be expected. Rather than inspire, the pictorial world has restrained the interpretative discussion. During the first half of the $20^{\text {th }}$ century the religious approach dominated, while the perspective of the $1970 \mathrm{~s}$ and ' 80 s focused mainly on manifestations of status. The 1990s marked a revival of interest in the ritual dimension of the rock-carvings. In this article it is argued that rock-carving interpretations ought to be integrated into the wider discourse, as well as into a local context of contemporaneous ancient remains. Another important task for future research is to study the meaning of the carving act, not only the significance of the images.
\end{abstract}

Katherine Hauptman Wahlgren, Department of Archaeology, Stockholm University, SE-10691 Stockholm, Sweden.

\section{THE INTERPRETATION PARADOX}

Many of us are fascinated by rock-carvings today, as were scholars centuries ago, and in spite of the article's title this interest does not make us lonesome at all. Nevertheless, it is tempting to view a major part of the rockcarving studies as lonesome sailings, not within but outside the general archaeological discourse. In that respect the rock-carving interpretations resemble the studied objects, the ships and other images that appear side by side on the rock, but seldom together in action creating easily defined contexts (fig. 1).

For an outside observer it may seem as if the average expert on rock-carvings today confidently masters a highly dependable and expressive material. At least, it is notable that many rock-carving interpretations consider only the carvings, opposed to an integrated understanding of complementary Bronze Age phenomena. On the other hand, many studies of for example, Bronze Age settlements and graves exclude the rock-carving problem or only mention the carvings briefly. To me it is somewhat of a paradox that this vivid and stimulating world of images has not inspired us to seek a deeper understanding of Bronze Age life and beliefs. On the one hand, we have this rich source of pictorial information that is often only casually referred to; on the other hand, we have few contributions of thorough, contextual interpretations that include studies of the relations among different types of ancient monuments. One of the more interesting tasks for future interpreters would be to reveal the tension between the presumably sacred rocks and the everyday life in 


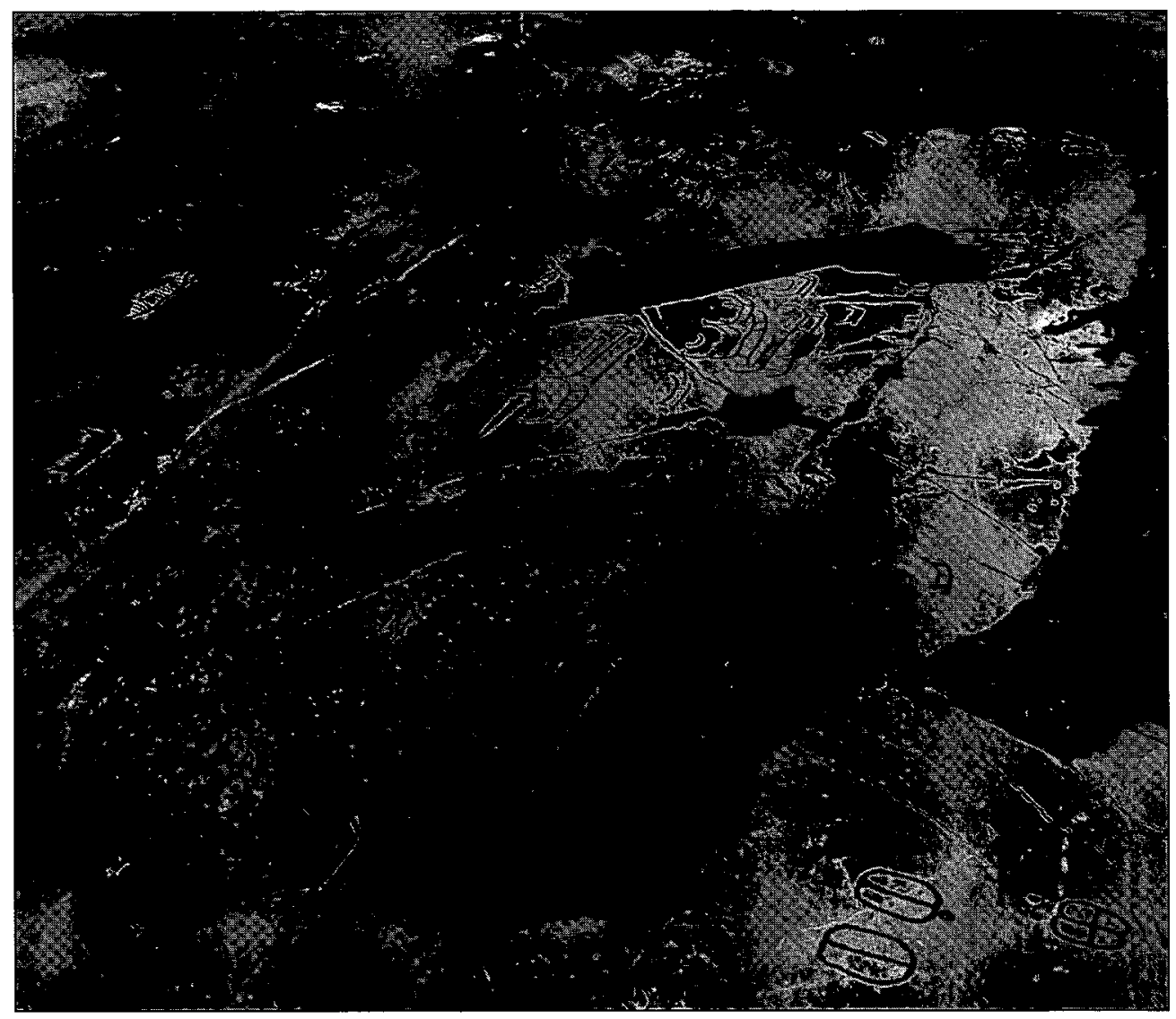

Fig. 1. A fleet of lonesome, sailing, rock-carving ships. Detail of rock-carving surface at Himmelstadlund, Norrköping in Östergötland. Photo: Arthur Nordén 1933, ATA.

the settlement area, together with graves, heaps of fire-cracked stones and other ritual expressions.

Until the middle of the $20^{\text {th }}$ century it was customary to make imaginative and inspiring interpretations. Unfortunately, one disadvantage of the research ideal that followed is that some of this creativity has been repressed. That has affected rock-carving studies in particular, since it seems obvious that it is impossible to comprehend the world of images simply by strict definition and categorisation. Maybe that is why only a few archaeologists have even tried. It is sometimes jokingly said that if you want to have a successful career in archaeology you should touch upon rock-carvings once or twice, but that it is suicidal to choose the subject as your main field of work. This is of course not true; a mere glance around reveals respected archaeologists who specialise in rock-carvings. Nevertheless, the number of modern Swedish dissertations on the subject does not reflect the wide range of rock-carving interpretations that could be expected (Nordbladh 1980; Burenhult 1980; Bertilsson 1987; Görman 1987; Lindqvist 1994). My impression is that many scholars rather treat rock-carvings as something imperceptible, and therefore save the interpretative perspective for shorter papers that do not allow them to paint a general picture. 
My own knowledge mainly concerns Bronze Age rock-carvings in southern Sweden, and consequently this article will concentrate on problems within that tradition. However, since studies of the North Swedish rock-carvings sometimes intersect the South Scandinavian discussion, they will to some extent be included here. I realise that this position makes me an easy target for the same criticism that I have of earlier research, namely the tendency to treat rock-carvings as a separate field of study with little regard to different contexts or chronologies. Ironically enough, by referring to previous interpretations, even though in a critical way, I am still trapped in the old structures.

It is also appropriate to mention that my view of the Swedish rock-carving debate is not the only one. Histories of research are usually accounts of earlier presented works, introduced as a journey from the past to the present, with comments on the approaches and results but without a summary of the conclusions or an evaluation of the field. One exception is a paper by Jarl Nordbladh, where he expresses a view that is more or less the opposite of my own. Nordbladh conceives of the rock-carving research as generally rich and vital, and argues that there is a lack of debate today because of the heavy burden of many earlier scholars (Nordbladh 1995). I would say that the apparent reluctance to create new interpretations during the recent decades is due to the limitations of the existing research tradition, rather than to a great respect for earlier interpretations. The history of research becomes a source material in itself; the chosen references give credit to your own work and a position in the general debate. Relying on authorities also provides an opportunity to avoid being criticised for loose ends in the argumentation, and allows you to get credit for laborious, but less controversial, work such as statistical accounts and documentation.

Outside the academic world on the other hand, rock-carvings are frequently subject to all kinds of fanciful interpretations centred on celestial phenomena and various calendars. Archaeology in general is of great interest to many people. Most of them do not care for scholarly discourse; they either want answers to what really happened in the past, or believe that they are better suited to find alternative, true explanations themselves. Rock-carvings seem to have a special attraction for theoreticians on the outer fringe. Perhaps the lack of archaeological interpretations necessitates the variety of fantastic histories.

\section{FROM CRUDE AMUSEMENT TO INTERPRETATIVE SIGN-SYSTEMS \\ Early rock-carving studies}

The earliest references to Swedish rockcarvings are from the $17^{\text {th }}$ century (Nordbladh 1981:G56), but it is only from the middle of the $19^{\text {th }}$ century an academic debate about their origin and significance begins to take shape. The $19^{\text {th }}$-century notes are still mainly reports of the discoveries of carvings with descriptions and drawings of the images. Examples of influential, early documentation are the works of Baltzer in Bohuslän and Nordenskjöld in Östergötland (Baltzer 18811908; Nordenskjöld 1870-73, 1876-77, $1880,1933-34)$. By that time the dating of the rock-carvings was the subject of two major works with completely opposite interpretations.

Axel Emanuel Holmberg considered the carvings mainly to have been made by people with access to iron tools and weapons, and the pictures to be based upon Viking expeditions and the Icelandic Sagas. He assigned them to the later period of Nordic heathendom, mainly because of the shape of the swords, which is ironic as the swords were conclusive for subsequent dating to the Bronze Age. Holmberg was convinced that the carvings could not have been produced with stone tools. The lack of characteristic Bronze Age ornamental styles in the openair rock-carvings persuaded him that the 
carvings, except for those inside graves, were unlikely to belong to the Bronze Age culture (Holmberg 1848:8-13, 18, 74).

In contrast to Holmberg, Carl George Brunius maintained that the rock-carvings could easily be produced with tools of stone, and that the primitively shaped images must mainly belong to the dawn of art and therefore should be dated to the Stone Age (Brunius 1868:76f, 81f, 150ff). He dismissed the possibility that the pictures were made by people of a higher culture, because he considered it unthinkable that they would concern themselves with such distasteful and unskilful carvings. Brunius was apparently upset by what he found to be a demonstration of uncivilised crudeness and in many cases loathsome depravity (Brunius 1868:84).

Shortly thereafter, the decisive step to finally date the rock-carvings to the Bronze Age was taken by Bror Emil Hildebrand. He compared carved sword images at a rockcarving site at Ekenberg in the province of Östergötland with similar swords in the Museum of National Antiquities, and concluded that the rock-carvings must be from the Bronze Age (fig. 2). He stated that it was impossible to mistake the period to which the sword belonged, and maintained that this type of sword only existed during the Scandinavian Bronze Age (Hildebrand 1869:425f). Although the datings have been partly revised, and the comparison between carved rock images and mobile objects can be criticised (Nordbladh 1980:27f), this is still one of the most important contributions to the rock-carving context.

\section{Fertility cult, death cult or some other cult?}

During the first half of the $20^{\text {th }}$ century, the rock-carving debate was dominated by a divergence of opinions on whether the images symbolised a fertility cult, or if they derived from a tradition of grave-carvings and served a cult of the dead. Oscar Almgren and Gunnar Ekholm subsequently became front-line

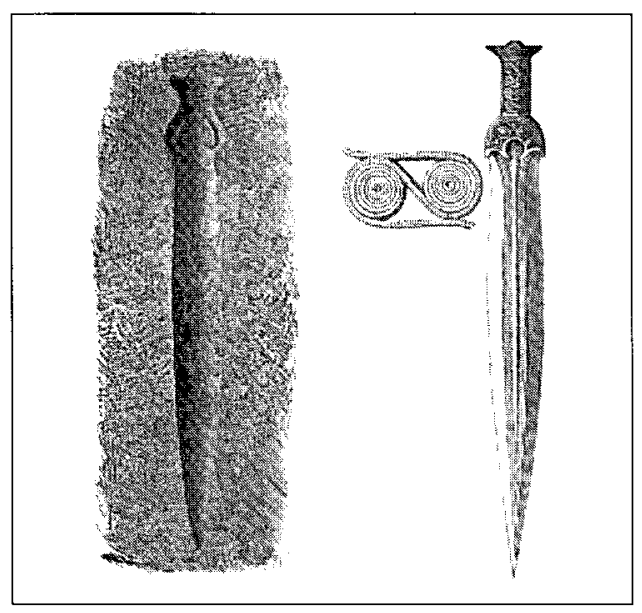

Fig. 2. By comparing rock-carving swords with similar artefacts in the Museum of Ancient Remains, Bror Emil Hildebrand concluded that the carvings should be dated to the Bronze Age (Hildebrand 1869:425).

figures for the respective lines of interpretation (major works on this theme: Almgren 1913, 1927; Ekholm 1916, 1921), although several other scholars also took part and position in what today may seem as a somewhat obscure controversy. My impression is that at least some of the disagreement was caused by misreading each other's texts, mainly due to differences in approach. While Almgren had a perspective based on the history of religion, and copied examples of cultic activities from all over the world, Ekholm studied the rock-carvings in a local context with consideration to other ancient remains. Although Ekholm appears to be archaeologically more modern, Almgren's view has been far more influential on subsequent researchers until today.

In fact fertility and death cults are not in opposition, but intimately woven together to create meaning in life as well as in death. The inconsistencies of this debate are quite clear in an extensive exchange of opinions between Bror Schnittger and Gunnar Ekholm in the journal Fornvännen (1922a, b). With inspiration from an earlier work by Almgren 
(1913), Schnittger argued that it would be meaninglessly altruistic of the Bronze Age farmers to consider sun and rain for the dead, when the living were highly dependent upon these factors for their existence. He found the whole idea of a death cult to be an idealisation of human nature (Schnittger 1922a:104). Ekholm, on the other hand, did not regard the cult of the dead as separate from the world of the living. He emphasised that graves and the care of the dead are a matter for the living people, and that, for example the ancient Egyptians believed that the sun-ship was similar to the death-ship (Ekholm 1922a:220, 226). Despite those comments, Ekholm maintained that there were no indications of fertility magic for the living people in the rock-carvings (a.a:221). The decisive difference between the views of Almgren and Ekholm is that Almgren believed that the images depict authentic fertility rituals, while Ekholm conceived of them as symbolic expressions (Almgren 1927; Ekholm 1921).

The religious theme, mainly according to Almgren, dominated rock-carving studies until the $1970 \mathrm{~s}$, and the theories of fertility cult, sun symbols and adoration are still influential today, although in other forms. To give a few examples of alternative lines of cultic interpretation, Carl-Axel Althin claimed that the symbolic figures, footprints, handprints and cupmarks had magical significance, and that they were carved as a protection against evil. He also maintained that the cultic act of carving figures in the rock was of primary importance, and that the completed image had lost its power. Therefore a new one was required on every occasion (Althin $1945 \mathrm{a}, \mathrm{b}$ ). This view would imply that the pictorial composition on the rock has no meaning, and that there is no point in studying the relations among the figures. Few rockcarving scholars would agree on such a conclusion, but Althin's emphasis on the ritual act is interesting and supplies a dimension that is often lacking in other studies.
The idea of hand signs as protection has later been developed by Mats P. Malmer. He argues that the stylized hand images that occur on the back of Late Bronze Age brooches, often together with two or four lines, signify protection. The extra lines serve to strengthen the magic either twice or four times (Malmer 1971, 1993).

Another interpretation that has often been referred to, is Bertil Almgren's idea of the presence of an invisible deity. He proposed that the carved footprints symbolise a god that people were forbidden to depict. In Almgren's view, several of the other images such as ships, circle-crosses, and cupmarks, are symbolic representations of divinities with both female and male sides (Almgren 1962). Almgren also suggested that the big kidney-shaped or rectangular outlines may depict life-sized cloaks and tunics, an interpretation that has been generally accepted (Almgren 1960). Mats P. Malmer adds that the contours of objects in natural size, for example clothing and weapons, must have been carved around the real object lying on the rock, and that the completed design symbolises a sacrifice (Malmer 1989a, b; 1993).

\section{Rock-carving documentation}

One of the prerequisites for detailed rockcarving studies is access to reliable documentation of the sites (fig. 3). Far from all Swedish rock-carvings are well documented, although several scholars have contributed to this work. The efforts made have nevertheless been indispensable to making the images available for further studies (fig. 4). I will mention only some of the major series of publications with figural documentation. In addition, there are of course accounts of individual sites as well as the National Register of Ancient Remains, and the continuous work conducted by universities, museums and amateur societies. But nowadays new discoveries tend to come in focus, and therefore they get more attention than already wellknown, but often poorly studied, rock-carvings. 


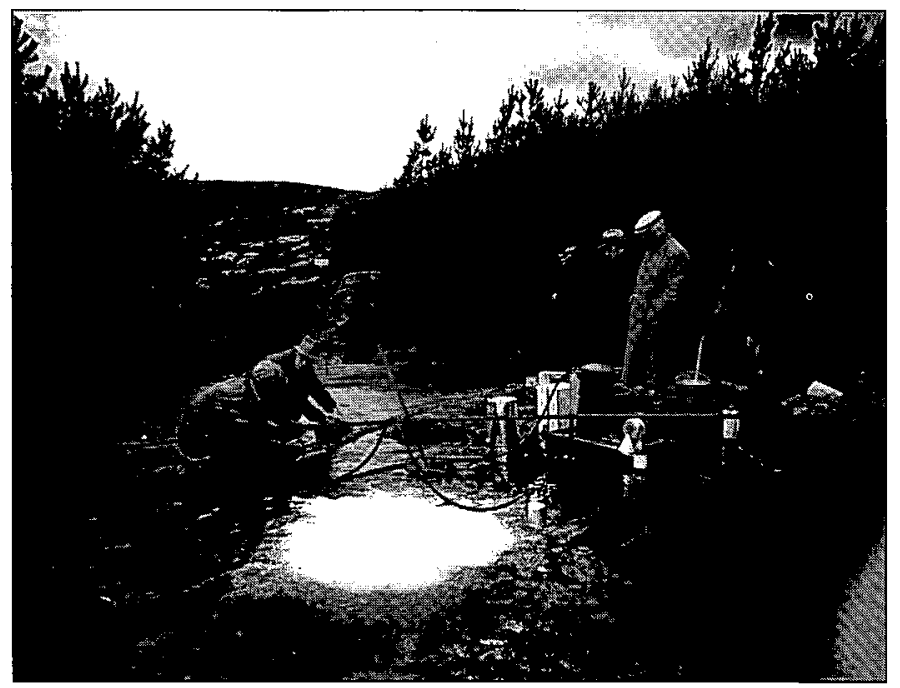

Fig. 3. Cleaning a rockcarving site in Tanum parish, Bohuslän. The scene seems to be from the late 1930s or the 40 s, and probably the rock is being prepared for filling in the images before documentation. Photo: ATA.

An early example of competent rockcarving documentation is the works of Arthur Nordén in Östergötland (Nordén 1922, 1925). He discovered numerous sites, mainly in the Norrköping area, and depicted the figures thoroughly. Another example is Carl-Axel Althin's documentation of the Scanian rockcarvings that is presented in sensitive and beautiful water-colour drawings (Althin 1945). The rock-carvings in a larger part of Götaland, excluding Göteborg county, Bohuslän and Dalsland, have later come in focus for documentation by Göran Burenhult (1973). His methods are qualified, but unfortunately the large-scale illustrations and the shortage of several known sites put limitations on the usefulness of the publication.

Among the areas studied by Burenhult, subsequent registration work has been published from, for example Västergötland and Dalsland. Peter Jankavs and the Falbygden Museum have for several years been working on new, substantial documentation of rockcarvings in parts of the county of Västra Götaland (formerly Skaraborg). Examples of illustrative plates from a few of the recorded sites are found in short papers (Jankavs 1996, 1998, 1999). Furthermore, Karin Rex Svensson and the Älvsborg County Museum have published the rock-carvings in Dalsland. The work includes both photos and drawings, and is interesting because sites with modern carvings of initials, names and dates are presented along with the traditional Bronze Age ones (Rex Svensson 1982). Recently the Vitlycke Rock Carving Museum in Bohuslän has contributed additional documentation from Tisselskog in Dalsland, based on the registrations by Tommy Andersson (Andersson 1997).

In Bohuslän the rock-carvings are so numerous that a comprehensive, pictorial documentation can not be expected for some time. However, regarding the island of Tjörn, in the southern part of the province, a comprehensive registration has been published by Johan Pettersson \& Gunnel Kristiansson. It includes descriptions, photos and some interpretations of the rock-carvings, but lacks drawings of the image surfaces (Pettersson \& Kristiansson 1977; Pettersson 1982).

In northern Bohuslän, accounts of a few parishes based on the works of $\AA$ ke Fredsjö have been available for several years (Nordbladh \& Rosvall 1971, 1975, 1981). Since the richest rock-carving landscape in Bohuslän, Tanum parish, was entered on the UNESCO's World Heritage List, the interest in rescue projects, inventories, registration and documentation of the rock-carvings has increased considerably. Such projects have 


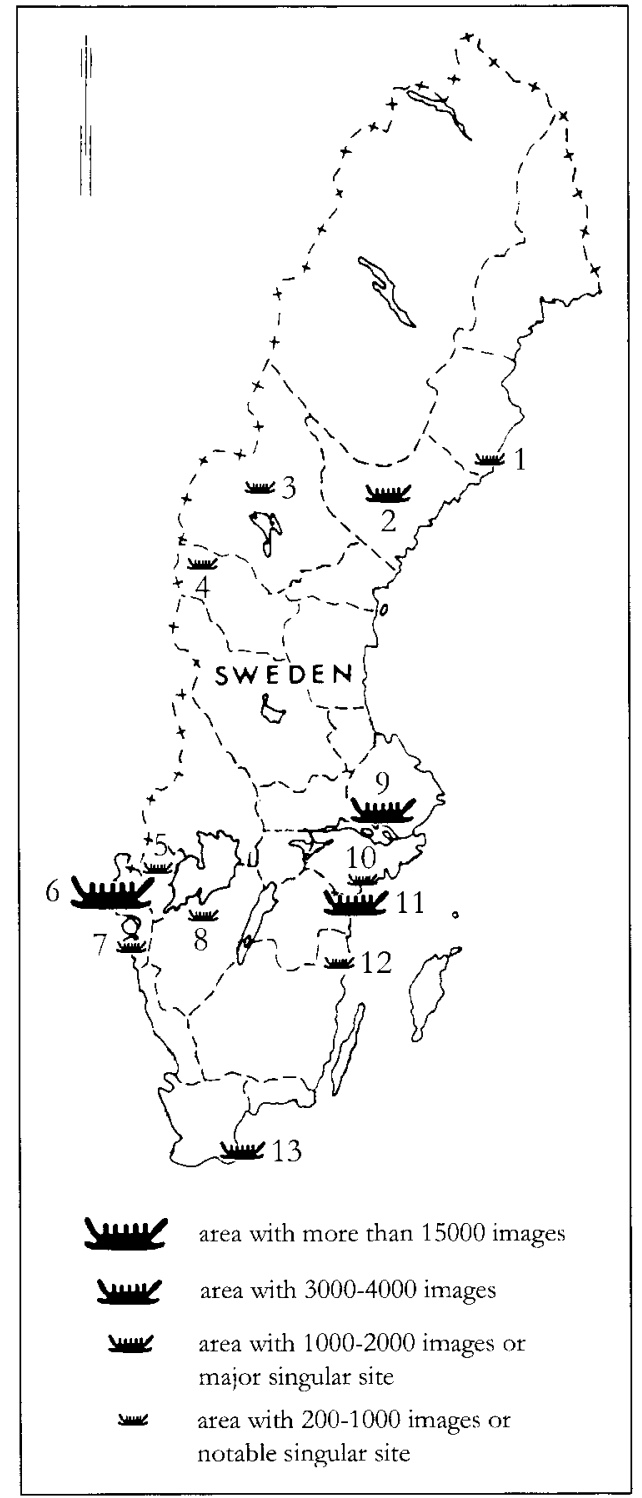

already been conducted for a long time by the two local rock-carving museums, the Vitlycke Rock Carving Museum (Högberg 1995, 1997; Bengtsson 1997, 1998) and the Scandinavian Society for Prehistoric Art (Tanums Hällristningsmuseum Underslös 1996, 1999). Several specialists on rock-carving inventory have, through ambitious work and thorough registration, contributed to the realisation of these reports.
Fig. 4. Major figural rock-carving areas and notable sites with carvings and paintings mentioned in the text. Sporadic sites are found in other areas, and the cupmarks have a markedly wider distribution, since they occur in almost all of Scandinavia during the Bronze Age.

Northern areas with rock-carvings and paintings: (1) Stornorrfors and Laxforsen, Västerbotten; (2) Nämforsen, Angermanland; (3) western Jämtland; (4) Flatruet, Härjedalen.

Southern rock-carving areas: (5) Dalsland, mainly Tisselskog parish; (6) northern Bohuslän; (7) southern Bohuslän, mainly on the island of Tjörn; (8) Västergötland, notable sites are Flyhov in Husaby parish, and Godegård in Fåglum parish (9) south-west Uppland; (10) Södermanland, notable site is Släbro, Nyköping; (II) north-east Östergötland; (12) Småland, Tjust, mainly the Västervik area; (13) south-east Scania, mainly the Simrishamn area.

Regarding Uppland, there is a general account edited by Åke Hyenstrand based upon the inventories of Einar Kjellén (Kjellén 1976). It includes descriptions of all registered sites and figures as well as some photographs, but it lacks drawings, which often are very useful for rock-carving studies.

Among the numerous rock-carvings that have been discovered during the last 20-year period, the large site at Släbroparken in $\mathrm{Ny}$ köping, Södermanland is one of the most spectacular (fig. 5). It was found in 1984 by Sven-Gunnar Broström and Kenneth Ihrestam, who have contributed notable inventories of several parts of the country. The specific world of images makes the carvings pictorially unique, and the amount of figures - more than 430 varied images and over 250 cupmarks - has definitely put the rather rockcarving-deficient province on the map. Documentation of the site has been published by Länsstyrelsen i Södermanlands län (Wigren et al. 1990).

Finally, let us briefly turn to a northern context. By documenting the large rockcarving sites at Nämforsen in Ångermanland and some other localities, Gustaf Hallström made an important contribution to subsequent 


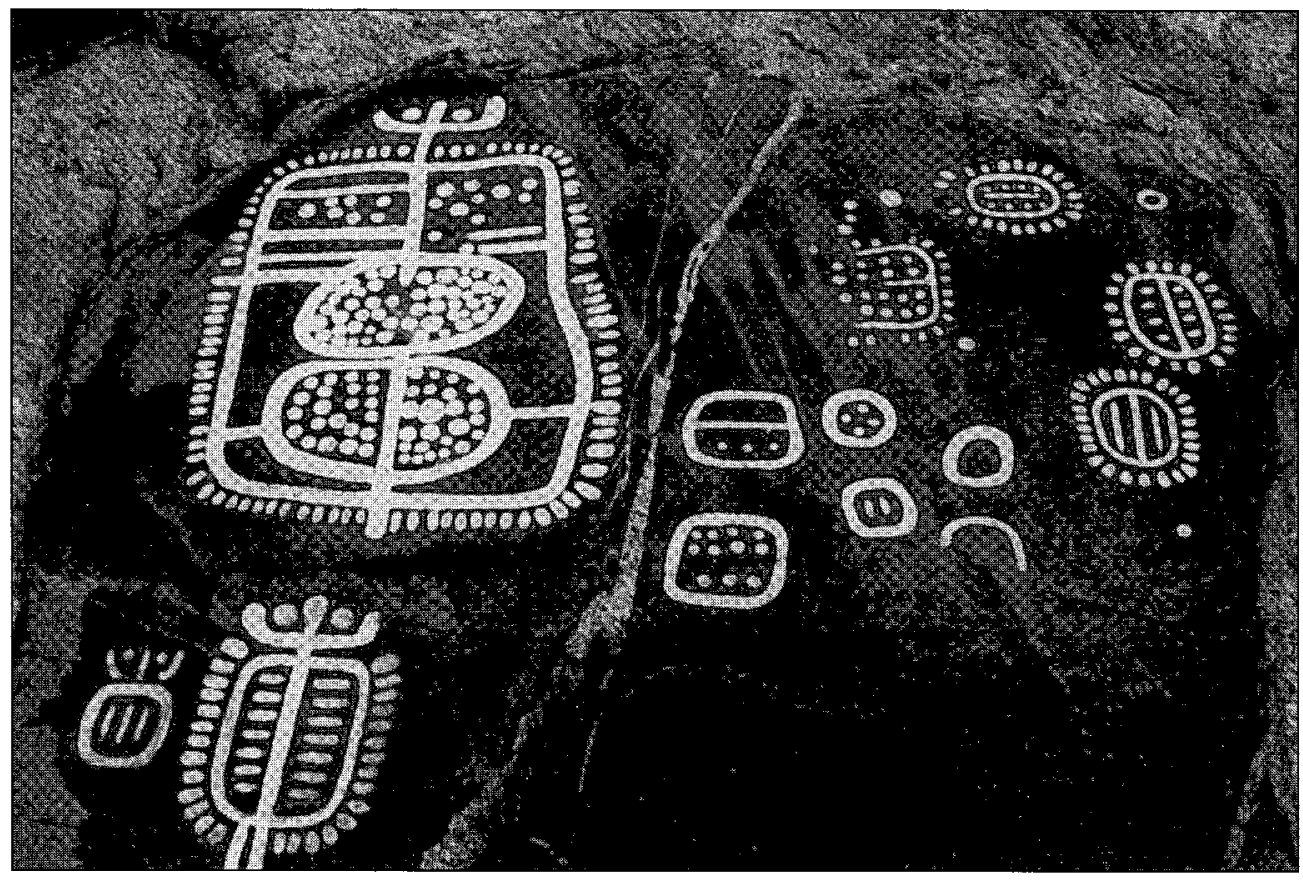

Fig. 5. The conspicuous rock-carving at Släbroparken in Nyköping, Södermanland, is strictly composed and consists of a coherent world of images that differs notably from other Scandinavian rock-carvings. Photo: Katherine Hauptman Wahlgren.

studies of North Scandinavian rock-carving traditions (Hallström 1960). Other examples of documentation of North Swedish rockcarvings are the works of Ramqvist et al. on Stornorrfors in Västerbotten, and a short account by Thomas B. Larsson \& Sven-Gunnar Broström that describes the recently discovered rock-carving site at Laxforsen in the same province (Ramqvist et al. 1985; Larsson \& Broström 1999).

Rock-carving documentation is very laborious and time consuming, and there can be difficulties in comparing different reports because of incoherence in registration and rendering. But unlike Jarl Nordbladh for example, I do not consider the lack of a completed comparable corpus to be the main restraining factor in rock-carving interpretation (cf. Nordbladh 1999:18). On the one hand further documentation is of great importance; on the other hand it is hard to deny that, although a considerable amount of rockcarving material is published and easily accessible, there is far from a corresponding endeavour regarding the interpretation of its meaning. Maybe it is time to make some serious attempts to get the most out of the available material and its potential, before requesting more registration.

The field of modern rock-carving studies

Until now I have touched only briefly upon some general interpretation trends and problems in the Swedish modern scholarly studies. However, there are some major works and fields of interest that are worth discussing in particular.

Like most of the earlier researchers, scholars of today still tend to work within a limited area or region. At least, there is a huge gap between the research on the South Scandinavian and the North Scandinavian rock-carvings. Although the southern and the 
northern traditions often are presented in the same anthology or at the same congress, they are treated as completely separate phenomena. The South Scandinavian carvings are traditionally called "farming engravings", and they have explicitly or implicitly been linked to the European Bronze Age and have therefore presumably been influenced from the south. It is also generally inferred that they carry complicated messages, but it is rarely specified what they may signify.

The North Scandinavian carvings, on the other hand, have traditionally been called "hunting engravings". Together with the rock-paintings, they have been conceived of as belonging mainly to the Stone Age and to have eastern links. However, there are also some indications of southern connections and of continued rock-carving activities during the Bronze Age (Bolin 1999:140f, with references; Larsson \& Broström 1999).

The northern rock-carvings are given a functional interpretation more often than their southern counterparts, with respect to ecological factors and subsistence. The most common interpretation regards hunting magic, where it is assumed that the people carved

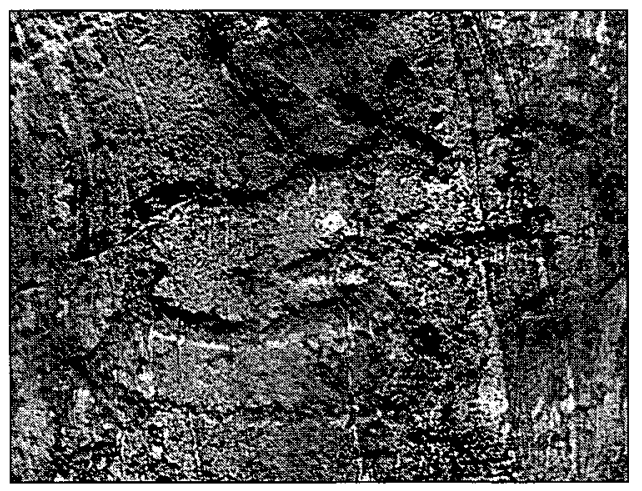

Fig. 6. One of the few northern examples of an elk hit by a spear is found at Nämforsen. AdalsLidens parish in Angermanland. The vast majority of the elk figures are depicted without visible connection to hunting. Hunting scenes are in fact far more common in the southern rock-carvings, mainly in the Norrköping area. Photo: Sören Hallgren. ATA. and thereby reproduced the important winter game, the elk (cf. Tilley 1991 and Bolin 1999 for contrasting interpretations). Elk figures also dominate in general, but despite the term "hunting engraving", depicted hunting scenes are in fact very rare (fig. 6).

More recent discoveries of rock-paintings in northern Bohuslän have complicated the picture with separate southern and northern traditions, but until now there are few comments on this issue (though ef. Nordbladh 1987). The popular-scientific anthology Hällristningar och hälmålningar $i$ Sverige, where many Swedish rock-carving scholars collaborate, is a good summary of modern rockcarving research up to the early 1990s (Janson et al. 1989).

Regardless of which region is studied, the problems with rock-carving studies (or rockart studies as they often are called to include the rock-paintings) are similar. Apart from the tendency to link the North Scandinavian rock-carvings closer to nature, fulfilling more primitive needs than the South Scandinavian, the scholarly traditions are comparable and, of course, to some extent influenced by the general archaeological debate from the $1970 \mathrm{~s}$ through the 1990s. Swedish rock-carving research also maintains a continuous dialogue with similar research in the other Scandinavian countries. I will mention the names of only a few of the scholars who are repeatedly referred to in Sweden, and who have written general works of importance to Swedish conditions, namely Egil Bakka, Eva \& Per Fett, P. V. Glob, Anders Hagen, Knut Helskog, Gro Mandt and Sverre Marstrander.

One of the most frequently considered problems in the rock-carving debate is the chronology. Most scholars touch upon this subject, either with their own observations or with reports of other studies to support their own position. Although there is consistency in the dating framework, it is still not an exaggeration to say that there are almost as many chronological variations as there are scholars. In several cases the efforts to create 
chronological models have dominated completely, and the researcher has rested with the result instead of penetrating the questions of why the rock-carvings were made and what they meant.

During the 1970 s it became possible to treat large amounts of data. For some time, large-scale quantitative analysis was the main focus of rock-carving studies, as well as in other fields of archaeology (e.g. Welinder 1974; Burenhult 1980; Bertilsson 1987). Systematic data treatment was a new approach, it created possibilities to get around the often disconnected hypotheses on the meaning of rock-carvings. In line with the New Archaeology, it was of course also an attempt to make rock-carving studies more scientific. With improved registration methods and statistical analysis it was possible to obtain other kinds of knowledge, based on systematic observation. The question of a religious meaning-content was successfully omitted in favour of a terminology that included concepts like carving technique, distribution pattern, territorial markers, rivalry and subsistence. Ironically enough, many of these studies conclude with remarks about the importance for future research to create cultural contexts, yet that is exactly what the writers had the chance to do and failed to do.

\section{Major works concerning modern rock-} carving interpretation in southern Sweden One of the few geographically transgressive analyses of the Scandinavian rock-carvings was made by Mats P. Malmer (1981). According to Malmer, it is necessary to examine the whole range of chronological and chorological factors before any further interpretations can be made. But it is notable that Malmer's own statistics are based on accounts from old publications, and not on data from the Register of Ancient Remains. With only a brief comparison, it is evident that the amount of figures that Malmer states for the whole of Scandinavia, is widely exceeded by the province of Bohuslän alone.
In order to categorise the rock-carvings, Malmer arranges the figures according to different typological elements, but he arrives at so many categories that they sometimes only contain single examples, which makes the model less useful in practice. For the South Scandinavian tradition, Malmer interprets an innovation course from the south towards the north. The rock-carving-rich areas in middle Sweden are mixtures of the southern and a separate northern hunter's tradition. Still, he regards images such as boats to be influenced by prototypes from the south, which makes a large part of the North Scandinavian rock-carvings younger than many other scholars believe. One problem with this approach, and the critique applies not only to Malmer, is the presumption that new ideas and changes in the society are always adapted from civilisations in southern or central Europe. The search for innovation areas eclipses the question of the meaning of the rock-carvings in the studied context, and paints a static picture by disregarding the inherent dynamics of a society. Another problematic point is the frequently referred to observation by Malmer that there are no quantities of so-called farmer engravings in the most fertile regions. Instead of reflecting on whether the thin association to farming is of decisive significance, he concludes that rock-carving is a marginal phenomenon, carried out by people in poor areas with limited economical resources. Consequently the depictions symbolise actual ceremonies and offerings in the wealthy districts (Malmer 1981, 1989a). These conclusions have also been heavily questioned, and nowadays scholars tend to view power over cultic expressions as crucial, and the rock-carving agglomerations as regional centres or strategic areas for communication routes (e.g. Bertilsson 1989a:38; Selinge 1989:154; Larsson 1993; Kaliff 1997:31f).

In his dissertation a year earlier than Malmer's study, Göran Burenhult concentrated on what he called the "picking 
technique" to create a chronological model for the South Scandinavian rock-carvings (Burenhult 1980). Through measurement of the carved lines, superimposed figures, and statistical data processing, he identifies eight different picking techniques and maintains that they have chronological implications. From these results he creates seriations of the different types of figures, which are visualised in a chronological scheme. An unconventional conclusion is that the oldest designs, zigzag patterns and circles, were introduced as early as during the middle Neolithic, and that the influence came from Ireland and the Alps. Another noteworthy point in the study is that the rock-carvings mainly are situated close to water, and that there is a difference in image-type between coastal and inland localities. Burenhult's interpretations are superficial and functionalistic, without regard to either profound religious or social meaning-content. Although Burenhult claims to work with objective procedures, the methods and the results have subsequently been criticised on several crucial points (Mandt 1982; Pettersson 1984; Selinge 1985).

In the same year as Burenhult, Jarl Nordbladh wrote a dissertation with a completely different perspective. Nordbladh has a semiotic approach to the rock-carvings in the studied area, the parish of Kville in Bohuslän. He sees the images as signs and parts of symbolic systems with communicative capacity. Six distinctive image-categories on every surface are analysed with regard to position, distribution and combination. Through structural similarities, he finds great unity among the sites and perhaps the basis of a sign language (Nordbladh 1980). Nordbladh's work stayed nearly uncommented for a long time, but during recent years it has become very important to a new generation of rock-carving scholars (e.g. Hedengran 1993, 1995). Recently Nordbladh has commented upon some problems with his own line of argumentation (Nordbladh 1999). He points out the emptiness of the term "con- text", which is often used today, and he mentions the traditionally problematic structuralistic position regarding chronology. The visualised patterns become synchronous, and there are difficulties in including dynamics and changes through time in the interpretations. When it comes to rock-carvings, this critique not only strikes at the structuralistic studies, but has relevance for a large part of the interpretative work until today.

In his dissertation of 1987, Ulf Bertilsson made another large-scale spatial analysis of the rock-carving area in northern Bohuslän. The main objective was to study the imagedistribution pattern, and the method consisted of quantitative computer processing of large amounts of data. The analysis shows that the rock-carving-rich parish of Tanum dominates, both in terms of frequency and figure variation. Bertilsson concludes that Tanum was the major centre of the rock-carving district, and that Kville and Sotenäs were minor centres. Unlike Burenhult, Bertilsson shows that the rock-carvings are linked more to the open arable land than to the Bronze Age shore-line. He interprets this pattern as the result of constant rivalry for access to newly elevated land from the sea, and as evidence he points to depictions of warriors and battle-scenes in the rock-carvings, as well as changes in burial customs, settlement and subsistence. This approach with statistical analysis, conflicts of power involving dominating people or groups, and the lack of interpretation with religious and ritual implications, is characteristic of its time and the research tradition. Bertilsson has supported this perspective in several articles (e.g. 1989a, $1989 \mathrm{~b}$ ), but during recent years his position has obviously become more ambiguous. Although he argues in favour of an approach that is more integrated with the ideology of the Bronze Age society, he still seems to support the view of the rock-carvings as expressions of the rise of a competitive society, where the depictions of weapons reflect warfare and everyday rivalry (Bertilsson 1995, 1999). 
A quite different picture of the South Scandinavian rock-carvings was painted by Marianne Görman in her dissertation on the history of religions (1987). She connects a large number of the images with the Celtic religion and the pre-Roman Iron Age. The figures are identified as Celtic deities, but the interpretations are out of context and Görman makes no attempt to understand the religious expressions she describes.

As is evident, Bohuslän has attracted the largest number of scholars through the years, but let us now turn to a different geographical region. Åke Hyenstrand's and Einar Kjellén's study of the rock-carvings in south-west Uppland is still one of the most comprehensive when it comes to interpretation and presentation of ideas (1977). They stress the importance of viewing the carvings in relation to the settled land, and observe that different ancient remains are spatially divided in the landscape. The rock-carvings are situated in the Bronze Age shore area; the cupmarks are found slightly above the pictorial carvings; further up there are heaps of fire-cracked stone; and the graves are placed even higher on the hilltops. A majority of the rockcarvings are concentrated to a limited area, within which the carvings can be grouped in geographical clusters. The images are carefully described in the study, and the final chapter articulates some of the most important questions concerning rock-carving significance. What is the meaning-content of the rock-carvings? To whom are they directed? Who made the carvings, and for what purpose? When were they made?

These questions may seem self-evident to anyone who is interested in rock-carvings, but in fact they are rarely verbalised and discussed. Although Kjellén and Hyenstrand do not give any answers, they touch upon issues that are crucial to an understanding of the rock-carvings. But in spite of some good insights, the spirit of the times is shown when the authors explain changes in the Bronze Age culture by a crisis in the society due to over-exploiting, climate deterioration, or economic factors.

\section{Interpretations of the rock-carvings in northern Sweden}

As mentioned earlier, the rock-carvings and paintings in northern Sweden have mainly been interpreted in terms of economy, subsistence and hunting magic (e.g. Hallström 1960; Baudou 1977; Ramqvist et al. 1985; Jensen 1989; Forsberg 1993; Lindqvist 1994). The recently discovered rock-carving site at Laxforsen is no exception. Thomas B. Larsson and Sven-Gunnar Broström claim that the images distinguish themselves from other sites such as Nämforsen or Stornorrfors. Although they maintain that the figures should be connected with the South Scandinavian Bronze Age tradition rather than an indigenous tradition, they still link the choice of carving place by the rapids to the importance of the river as an economical resource and to salmon fishing (Larsson \& Broström 1999).

In Norway, however, there is a continuous discussion in which the North Norwegian rock-carvings are assigned to a more complex ritual context (e.g. Hood 1988; Sognnes 1994; Helskog 1988, 1995, 1999). Similar perspectives have until recently seldom been proposed for the North Swedish region (cf. Tilley 1991; Bolin 1999). Perhaps the differences between the Norwegian and the Swedish discourses are evident partly because of the intriguing relationship between the so called hunters' and farmers' rock-carvings, which sometimes occur together on the same rock surfaces in Trøndelag, Norway. The two traditions simply have to meet, also among the archaeologists.

In the studies of North Swedish rockcarvings, the large site at Nämforsen in the province of Angermanland has heavily dominated the research. In addition to the environmental approach, many of the scholars have focused on chronology. Furthermore, the site has become the basis of a number of chronological models and dating 
discussions through the years (i.a. Hallström 1960; Malmer 1981; Lindqvist 1983, 1994; Baudou 1993; Forsberg 1993).

In contrast to the earlier works, it was refreshing when Christopher Tilley published a semiotic study of the Nämforsen rockcarvings (1991). Tilley's application of the textual metaphor has reverberated far beyond the North Scandinavian rock-carvings. He literally treats the rock-carving material as a text and the rock surfaces as pages in a book, which is compared to an anthology where different people write separate sections on different occasions. The distinction between the book Nämforsen and an ordinary book is that the book Nämforsen is not read, but written by the observer. Tilley works with structuration and binary oppositions on several levels, and he interprets the most common image, the elk, as a female symbol, while the boat-image symbolises the male. Each design-category such as fish, bird, tool, and shoe sole, together with the elk and boat, also symbolises a clan. The elk clan can be related to land, nature and inside, while the boat clan is water, culture and outside. Every category has a fixed position within the scheme, which defines its relation to the other categories. The interpretations are illustrated with ethnohistorical examples from the Evenk groups in western Siberia, and the Evenk cosmological system with shamanistic rituals is applied to the Nämforsen rockcarvings. Subsequently Tilley interprets Nämforsen as a mythological site, where elements of the cosmological system are inscribed to materialise myths about the world and the people living in it.

Although Tilley provides an interesting and profound framework for the contextual interpretation of the Nämforsen rockcarvings, there are still some problems with his approach. The carving tradition took place during a long time, probably several hundreds of years. Tilley's interpretations are coherent and contain different levels of meaning, but they do not allow inconsistencies or changes in belief and use of the sacred place and its symbols. The absence of a time dimension is often a shortcoming in structuralistic and semiotic studies. Unfortunately it also puts limitations on the interesting interpretations of significance and meaning-content.

In relation to Tilley, Hans Bolin has recently proposed a slightly different interpretation of the shamanistic rituals and the elk-boat concept. Bolin links the rockcarvings and paintings in the provinces of Angermanland and Jämtland to a cosmological system of ancestral cult. He suggests that the principle behind the depiction of elks was based upon the belief of descent from a mythical elk ancestor, and that the elk-boat associations of the rock art imply ancestral journeys along the rivers and waterways. The ancestors stopped at certain places to dance, these sites were linked to mythical events, and various shamanistic rituals were performed there. Unlike many other scholars, Bolin does not consider the rock-carvings to be the result of a static religious system. New motifs, for example those inspired by the southern Bronze Age, could be incorporated within the existing beliefs. Perhaps the mythology of ancestral elks was transformed through new situations, but the traditions lived on (Bolin 1999).

\section{The male world of rock-carving inter- pretation}

After this brief exposé of Swedish rockcarving studies, it is time to mention a few more of the ideas and perspectives that have left impressions on and been influential in the discourse. Although I believe there is a shortage of interpretations concerning rockcarving meaning, there are on closer consideration several, perhaps more or less subconscious, understandings that bias the general view of rock-carvings.

Evidently most of the Scandinavian rockcarving scholars of the past as well as the present, are men. In fact the male dominance exceeds many other fields of archaeology. 
As could be expected, the interpretations either implicitly or explicitly presume that men made the rock-carvings for other men, and that they depict male activities in a maledominated world. This has affected everyone who has come in contact with the rockcarvings, and probably their subsequent interpretations as well, including of course myself. It is noteworthy that even the generally accepted view of a fertility cult is male-centred with reference to phallic men, presumed sun symbols and a farming cult, and rarely to women, motherhood or childbirth (although cf. Mandt 1986, 1987; Bengtsson 1999).

The main lines of interpretation concerning the South Swedish rock-carvings have for some time focused on public spheres, trade routes for the valuable bronze, meeting or market places (Malmer 1981; T. B. Larsson 1989, 1993, 1999; Bertilsson 1989a), and manifestations of status, power and warfare (Bertilsson 1987,1989b, 1999; Nordbladh 1989; Malmer 1989a, 1993; Randsborg
1993). Regardless of the area studied, these sometimes isolated hypotheses are strongly biased by the general view of the male rockcarvings that in turn is coloured by a few of the well-known carvings in Bohuslän. The conspicuous large warriors, together with less striking armed figures and phallic figures, have become defining almost all of the human images (fig. 7). Although it is well known that a majority of the humans can not be determined as either male or female, but to us appear as neutral, several scholars maintain that practically every depicted human is a man (e.g. Selinge 1985; Malmer 1989b; Yates 1993). Even when it is not stated outright, in many texts it is inferred between the lines that the humans are men. Women are usually only mentioned in terms of how problematic and difficult it is to identify them or other female symbols among the images. In this perspective it is not surprising that it has been suggested that the abstract and long since disregarded cupmarks are female sym-

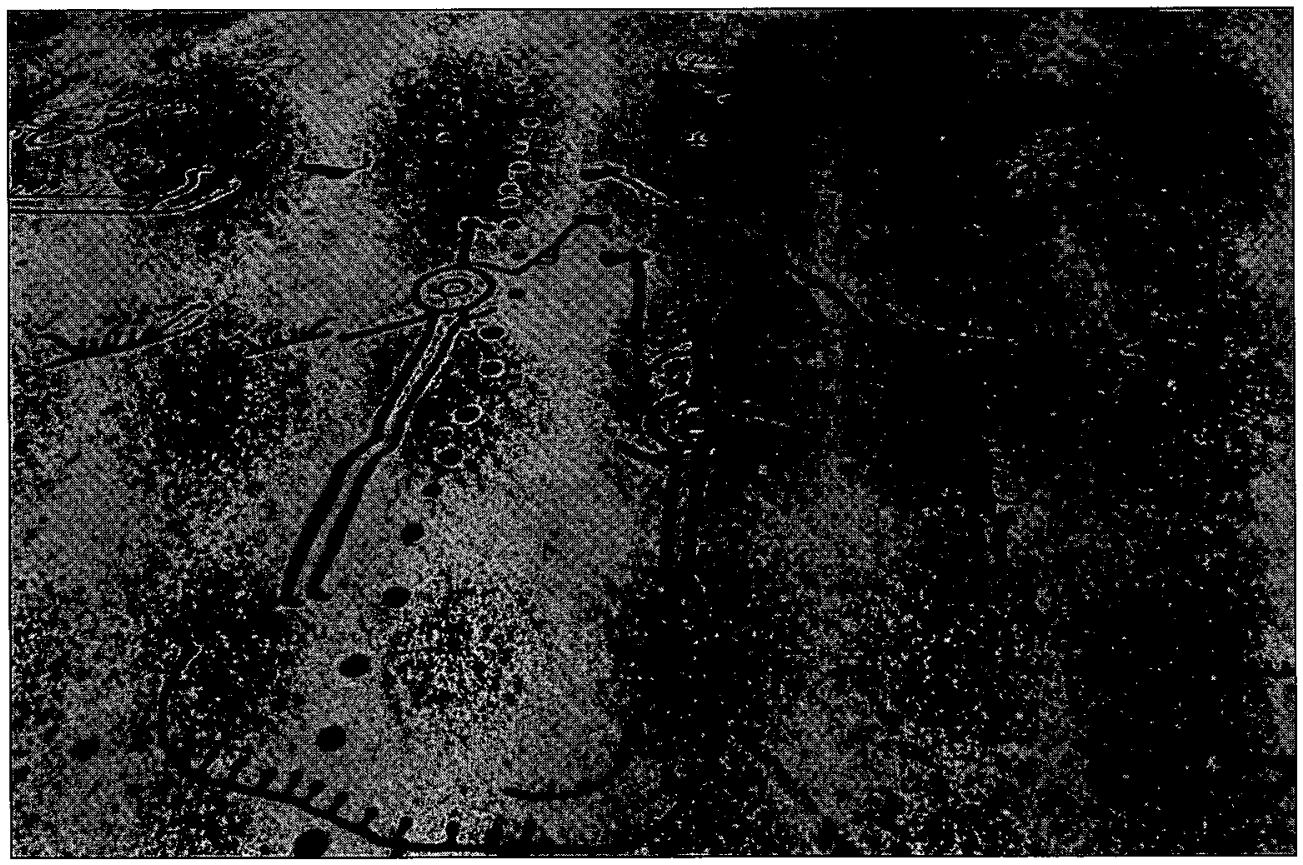

Fig. 7. The so-called border conflict. A well-known scene from Vitlycke in Tanum parish, Bohuslän that is often interpreted in terms of an ideology of rivalry or warfare. Photo: Mats Wahlgren. 
bols (e.g. Mandt 1986, 1987; Bengtsson 1999). In rock-art studies the interest in cupmarks, although they are by far the most common design, has been almost as low as for women.

Only a few attempts have been made to analyse the rock-carving gender relations, mainly in short papers. In Norway, Gro Mandt has searched for representations of female deities in the Scandinavian Bronze Age, as well as discussed representations of gender in connection with the Stone and Bronze Age rock-carvings in western Norway (Mandt 1986, 1987, 1995). Mandt identifies several images in the South Scandinavian context that could represent women or female deities, and she interprets them as fertility symbols. Femaleness is proposed to be symbolised by cupmarks, ships, carts, foot-soles, circle-crosses, trees, snakes and spirals (Mandt 1986).

Another Norwegian example is Knut Helskog's use of ethnographical analogies to explain maleness and femaleness in the Alta rock-carvings. According to him, maleness started to dominate during the last phase of the Alta carvings, and without femaleness the cosmological concepts of the rock-carvings became inadequate. The communication with the spirits shifted from the public rocks to a few ritual leaders, and the equivalence between maleness and femaleness was continually represented on, for example, mobile drums, while the rock-carving tradition disappeared (Helskog 1995).

Concerning the North Swedish material, it is notable that Christopher Tilley includes a duality in the Nämforsen rock-carvings. The boats are male symbols, but the most common image, the elk, symbolises the female (Tilley 1991). Like Tilley, Britta Wennstedt Edvinger has a semiotic approach, and uses a textual metaphor in her study of human and animal representations from middle Norrland during the Stone Age. Unlike Tilley, she has an explicit aim to work with gender relations. Most of the figures are difficult to determine in terms of biological sex; rather, they seem to be neutral in this respect. Among the human figures that can be identified as women there is a connection to elks, but neither women nor men are associated with boats, whereas neutral figures do have a link to boats (Wennstedt Edvinger 1993). The results are interesting, not least because of the commonly implied domination of a male sphere with boat journeys and hunting game in the northern rock-carvings. Therefore I would have wished that Wennstedt Edvinger drew further conclusions from her own study. In order to provide an alternative base for subsequent interpretation, further discussions are required.

Lastly, we return to the South Swedish rock-carving context. Based on a study of more than 260 rock-carving sites in Bohuslän, Lasse Bengtsson argues that cupmarks pecked in natural cracks in the rock symbolise the female sexual organ, and that the connection between cupmarks and graves can be interpreted in terms of fertility and the regeneration of life (Bengtsson 1999). In this perspective the small share of female representations suddenly increases to include a substantial amount of the rock-carvings. Thus, to add credibility to this interpretation, there is still need for a discussion of the relation between pictorial rock-carvings with a variety of images, and the many sites dominated by cupmarks that occur in different contexts. In a similar way Inger Hedengran has earlier noted the consequences of interpreting the so-called crew lines in ship images in relation to the more naturalistic human representations. The conventionalised crew is usually neutral, and by identifying the symbolic lines as humans, the male share would be markedly reduced in favour of individuals and a collective of women and men (Hedengran 1993:177).

Timothy Yates is one of the few scholars that discuss sex and gender relations in the rock-carvings more profoundly. But he does not take an interest in female representations; 
on the contrary, he uses psychoanalytical theories to focus on different male identities. As already mentioned, Yates argues that all the humans are men, even the ones that earlier have been interpreted as women, and that the carvings focus on aggressive masculinity (Yates 1993).

Furthermore, in a recent study concerning the rock-carvings at Högsbyn in Dalsland, Tilley touches upon the gender aspect in his interpretations (Tilley 1999). He maintains that the rock-carvings include sequences of narrative about becoming human and the process of establishing social and sexual identity. The important stages in the life and death cycle are intimately linked to other cycles of nature, such as seasonality and the passage of time. Although Tilley does not explicitly exclude women from the carvings, his interpretations consider the creation of male identity. The neutral humans are described as sexless and child-like, while the fully developed men are phallic and carry weapons. The final stage is symbolised by a sexual scene between two persons. Following Yates (1993), Tilley believes that they may both be male (Tilley 1999:167ff). It is true that homosexuality has been more or less absent from archaeological interpretations and that this aspect is worth some attention, but by pronouncing a male homosexual perspective in this context, every sign of female representation is effectively erased. Perhaps that is in line with the proponents' view of the rock-carvings, but why does it not necessitate further argumentation?

\section{The revival of interest in religious inter- pretations}

The non-mythological line adopted by researchers in the 1970s and ' $80 \mathrm{~s}$, with attempts to include social implications although forwarding a male bias, was a reaction against the previous domination of religious interpretations. It was generally considered that the rock-carving studies had come to a dead end, and that the methods involving identi- fication of different deities and parallels to Mediterranean conditions were not sufficient to learn anything about the society.

Today we can see a revival of interest in the religious dimension of rock-carvings and Bronze Age life, together with discussions of different aspects of ship symbolism and the dimension of ships as eschatological representations (e.g. Artelius 1996; Kaliff 1997), although some scholars still emphasise the importance of ship motifs mainly as representations of real conditions, with only brief mention of religious symbolism (e.g. Kaul 1995). But the main religious focus is not comparable to the former descriptions of divinities, even though studies of contacts and parallel symbolism with southern Europe do exist (T. B. Larsson 1997, 1999). Inspiration is sometimes drawn from the old imaginative works, but the current emphasis is rather within a theoretical framework including metaphoric thinking, symbolic expressions and ritual aspects (e.g. Hedengran 1990, 1993, 1995; Tilley 1991, 1999; Yates 1993; Bradley 1997a; Bolin 1999; Goldhahn 1999). If the Swedish scholars earlier were influenced by their Nordic neighbours, with world-wide excursuses, their interest is now directed towards theories developed mainly by British archaeologists and applied either to Scandinavian or international rock-carving material (in addition to the previously mentioned also e.g. Tilley \& Thomas 1993 and Bradley 1997b). Unfortunately there is still often a divergence between an abstract, theoretical level of discussion and particular studies of separate images or sites.

Concerning the northern rock-carvings and paintings in Sweden, as well as in Norway, there is a growing interest in shamanistic interpretations, where the rock-carving sites are assigned liminal qualities (e.g. Tilley 1991; Bolin 1999; Helskog 1999). I believe that this line of thinking will also make a notable impression within studies of the South Scandinavian rock-carvings in the near future. 


\section{THE LONESOME SAILING SHIP}

\section{Rock-carvings in isolation}

After this retrospective journey, is it still relevant to argue that rock-carving studies are lonesome sailings? During the expedition I have, of course, come across interesting works as well as several attempts to interpret the meaning of rock-carvings. However, I am far from satisfied. Regarding the amount of research, I would have expected a wider range of interpretations and more attempts to profoundly understand rock-carving significance. Furthermore I believe that the rockcarvings have been, and still are, suffering in isolation from the more general discourse. And I do consider this to be a disadvantage. It is true that rock-carving studies share the segregation problem with several other groups within archaeology, but nevertheless it remains a specific dilemma.

Certainly specialists are needed, since it is not possible for every archaeologist to be knowledgeable in all the fields of archaeology, not even in every aspect of the Bronze Age. But there is a significant difference between concentrating exclusively on profound yet narrow investigations, without links to a broader spectrum of problems, and using, for example, rock-carvings as a point of departure for further discussions on Bronze Age beliefs or social life. The problem with most modern rock-carving studies is that they either concern detailed image analyses, or do not emanate from the rock-carvings at all but instead seek connection with the European Bronze Age in a wider perspective. In order to create a context where the rock-carvings become understandable, several interpretative levels in between are needed. This dilemma is worthy of some reflection. What is it about the rock-carving material that prevents the archaeologists from apprehending other Bronze Age expressions? It seems selfevident that interpretations of rock-carvings are in great need of a social context with links to other contemporaneous phenomena. In spite of that, it is noticeable that even the semiotic studies tend to treat rock-carvings as sealed systems of signs (e.g. Nordbladh 1980; Tilley 1991).

Even when joined in a fleet, each study is still a lonesome sailing

On one level there has been a tendency to conceive of rock-carvings as works of art, which is evident in the frequently used term Rock Art to denominate the images. Though it is often emphasised that the term is chosen in order to include both rock-carvings and rock-paintings, the semantics are important for our comprehension of the phenomena. It can also be added that the term is internationally accepted and common in studies of rock-carvings and paintings in other parts of the world. The association to studies of art could be an interesting approach if it extended beyond the traditional view of aesthetics and ready-made artworks to include some thoughts inspired from modern art theory, which analyses art in relation to the society in which it is created. Regretfully, the rock-art studies do not infer that kind of dynamics, and in that respect they do not distinguish themselves from studies of engravings, rock-carvings, rock-paintings or petroglyphs. In fact, it is odd that linguistic metaphors have had an impact on the interpretations, while the more adjacent theories of image analysis have been left out of the discussion.

The way in which the rock-art terminology has been used has instead strengthened the view of rock images as passive pictures and excluded the dimension of ritual action. That perspective was abandoned a long time ago in general archaeology, so no wonder it is difficult to link the rock-carvings to other prehistoric phenomena. As long as the rockcarvings are seen as static products of society without the ability to affect life, traditions and beliefs, they will be superfluous in any interpretation that does not concern the rockcarvings in particular, and consequently uninteresting to most scholars apart from the 
rock-carving experts themselves. This is, of course, a disadvantage also for those devoted to the study of rock-carvings: in the long run, there is little chance of learning more about the meaning of rock-carvings without creating comprehensive contexts.

There is a feeling of affinity among scholars who deal with rock-carvings and rock-paintings from different periods of time, all over the world. For Swedish scholars it has often been more tempting to make crosscultural comparisons regardless of geography, climate or time, rather than to find connections between rock-carvings/rockpaintings and contemporaneous phenomena in the adjacent surroundings. National and international rock-art congresses are frequently arranged. They attract many scholars and have resulted in several reports. The latest publication from an international rock-art conference in Scandinavia, with contributions from several parts of the world, is from the Alta Conference on Rock Art in Norway in 1993 (Helskog \& Olsen 1995). This anthology, as well as other congress reports, collects a number of very divergent papers with one thing in common, namely the subject of rock art. The problem is that, although the studies are brought together, they are separate examples, and there are few obvious links that would motivate an interest in conditions on the other side of the world at the expense of local contexts. Even when joined in a fleet, each study is still a lonesome sailing. It would be far more interesting if some mutual inspiration would show up among the contributors.

I do think that international contacts are meaningful, and that there is a great deal to learn from scholars in other countries; for example there are several, recent, inspiring works partly based on ethnographical records from Australia and southern Africa (see e.g. articles in Dowson \& Lewis-Williams 1994; Chippindale \& Taçon 1998). However, by linking the materials together rather than discussing the different contexts relating to "rock-art", the traditional view of rock- carvings as a separate field of research is preserved. Rock-carvings and paintings, sometimes with a similar appearance, exist in many areas around the world. They are created in different periods of time and have different cultural implications. Discussions concerning the reference for separate traditions that must have started independently of each other, without a common origin, and why people have a need for these expressions, would be motivated.

\section{The importance of local rock-carving contexts}

The above points of discussion can be raised within the Scandinavian example. If it is possible to create rock-carvings without external impulses from a single provenience, would it also be conceivable that the Scandinavian rock-carving areas, and the different modes of expression, have greater difference in meaning, and perhaps also in chronology than we usually think? The figural rockcarvings are clearly concentrated to a few limited areas with large, more or less empty zones in between (cf. fig. 4). These rockcarving areas, such as northern Bohuslän, the vicinities of Norrköping and Enköping, and Nämforsen, may have been places for large gatherings of people who came from distant parts of present-day Sweden. Or maybe the rock-carvings were not a concern for all people but only for certain social groups, or for persons with special religious and ritual functions. The areas with rock-carvings may have been chosen because of their liminal position between land and water in landelevation territories (cf. Helskog 1999). They could also be centres where main waterways and land routes converged. Although far from every rock-carving site has been shore-bound, a common characteristic is their location in a space between the settled land and the sea. Another possibility is that the rock-carvings were needed only by people in certain areas, and that they are specific cultural expressions for those areas. Maybe the reason for main- 


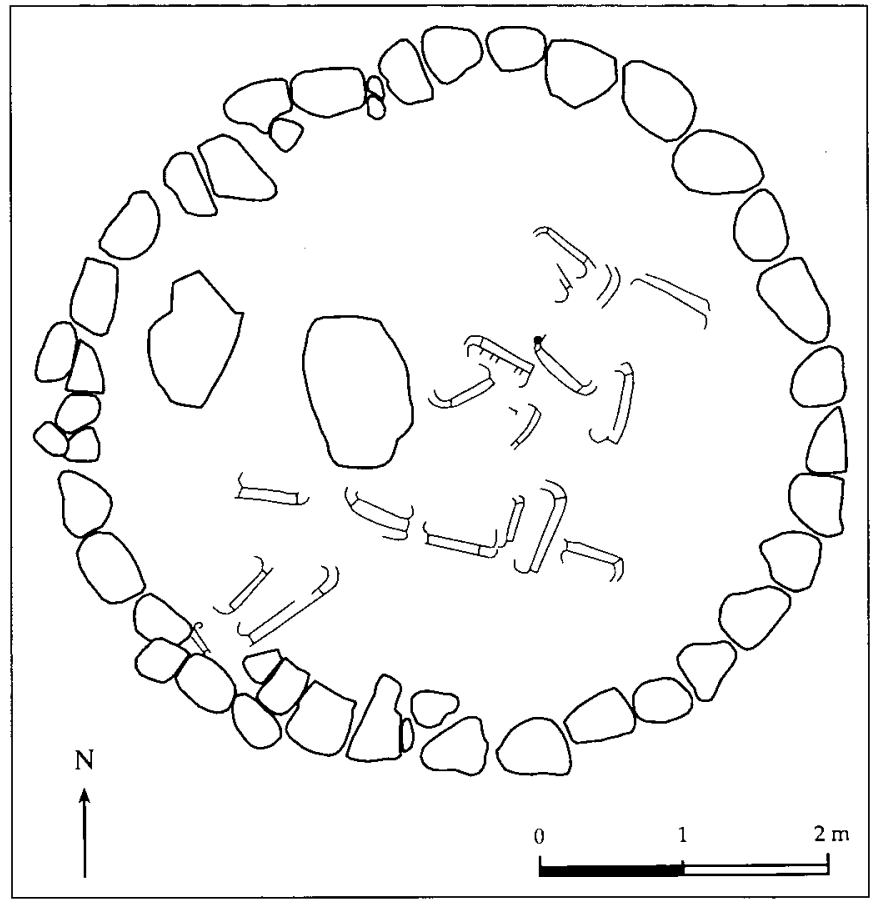

Fig. 8. Drawing of the inner kerb of stones and the carved ship images within the Hjortekrog cairn in Småland (Widholm 1998:76).

Hjortekrog, Småland, that was placed directly on top of several ship images (fig. 8). In his dissertation, Dag Widholm has interpreted the grave and the carvings as parts of a completed ritual that included both the carving of ship images and the burial of a man (cf. also Hedengran \& Janzon 1999). In contrast, there are other places in the area that show connections among graves, cupmarks and rock-carvings, but they seem to represent more continuous ritual activities associated with the cult of the dead (Widholm 1998).

In connection with the new registration of rockcarvings in Bohuslän in the early 1980 s, Ulf Bertilsson noted a cairn at Anneslätt in Askum parish that had been

taining such a tradition differed among the various areas; perhaps they suffered from conflicts of power that made expressive rituals necessary, or perhaps the liminality of the landscape inspired a cultural counterbalance to the powers of nature. These are only a few suggestions for lines of interpretation in a local context, and certainly there are additional alternatives as long as they take the specific prerequisites into consideration.

In connection with the discussion above, it is important to mention that there are a few examples of contexts with rock-carvings and cupmarks inside or under graves. The most well-known are the spectacular Kivik and Sagaholm graves (Randsborg 1993; Wihlborg 1978; Goldhahn 1999). They seem to be very special cases, however, and it is not certain how these grave-carvings relate to the openair rock-carvings in general. Another intriguing grave-carving context is a cairn in partly removed and appeared to cover some rock-carvings. He also refers to a site at Åby in Tossene parish with an upright carved slab in a burial mound, and points out that similar examples are known from the province of Halland and from Denmark (Bertilsson 1985:215ff).

During the excavation of the large Fiskeby cemetary in Norrköping another interesting relation between rock-carvings and graves was revealed. Several rock-carving surfaces were discovered at the outer edge of the cemetery. Although the period of burials covers a time span from the late Bronze Age to the Viking Age, the graves have only rarely been allowed to expand over the rock-carving surfaces (Lundström 1965, 1970; Hedengran 1989:89). In the Norrköping area there is also evidence of heaps of fire-cracked stone or layers of conglomerated cracked stones, soot and coal adjacent 
to, or covering, rock-carving surfaces (Nordén 1925:62ff, 81ff, 88ff, 102; Bellander 1938:93ff). In addition, rock-carving surfaces affected by fire are common in several areas (cf. Nordén 1925; Kjellén \& Hyenstrand 1977:8; Malmer 1989b:15). The study of these kinds of complex landscapes is also important for future research on rockcarvings.

In order to make thorough interpretations, however, it is difficult to ignore the problems with closer dating of the Scandinavian rockcarvings. I do not ask for particular typologies of the images; there have already been several attempts and I am not sure that they have left us much the wiser. But there is a huge difference between whether a rock-carving site has been used frequently for a limited span of time, or if it had significance during a very long period. It might be important for the understanding of rock-carving meaning to distinguish between rock-carving places with different prerequisites. Variations in topographical placing or image content can imply differences in meaning. These variations may be synchronous, but they can also indicate changes in the society, or in the religious beliefs that affect the use of rock-carving symbolism. Therefore it is also of interest to study the inconsistencies within and among sites, and not just seek the structural similarities.

\section{The unattainable rock-carving}

Let us return to the paradox mentioned in the introduction. This rich and vivid pictorial material that ought to stimulate the imagination and literally scream for interpretation, on the contrary becomes mute and unattainable. Instead of having their curiosity sparked, the archaeologists are left unappreciative before the world of images, not daring to declare anything about their meaning. This is quite a contrast to the thorough interpretations that are often based simply on some potsherds, postholes or waste at a settlement. My impression is that ancient remains that are excavated, or are possible to excavate are subconsciously thought to embody a greater potential of knowledge than, for example, rock-carvings. Excavated remains can be deciphered with modern research methods, as opposed to the unintelligible images that lack stratigraphy and rarely occur in closed contexts. The frequently used archaeological toolbox is not sufficient when it comes to rock-carvings.

A pragmatic view is that there are more practical phases in research that is based upon excavation. The work itself generates a product, a novelty that is rendered in a documentation, and insufficient interpretation of the material becomes less apparent. Rockcarvings, on the other hand, which can not even be dated traditionally, become an insecure and non-scientific material which is troublesome to interpret in a reliable way. Of course it is possible, and of importance, to make inventories of rock-carvings, to document the images, and to work on preservation issues, but somehow the insufficient attempts to interpret their meaning-content are all too noticeable.

Excavation has of course been tried on open-air rock-carving sites. During the $1980 \mathrm{~s}$ and 90 s several excavations were made in southern Sweden, but unfortunately they rendered few results. A source of inspiration for these attempts was the two quite successful excavations that were conducted in the mid ' 70 s by $\varnothing$ ystein Johansen in $\emptyset$ stfold, Norway. Johansen discovered stone constructions in front of the carved rock on both sites, and interpreted them as enclosures of a sacred area. Other finds were pot sherds, burnt clay, fragments of burnt bone, flint flakes, and a small stone with a carved line (Johansen $1979,1980)$. Swedish scholars hoped to come across similar remains, but the excavations consisted of only small test-pits with very few finds as a result, and perhaps the places had not been chosen carefully enough (Nordström 1995). When the anticipated new knowledge about the rock-carvings failed to appear, the 
interest in such excavations faded. However, I still believe that well thought-out projects in the future could be valuable, as long as the main complex of problems concerns a wider context in which the rock-carvings were significant.

To sum up some of the ideas that have been outlined, it appears as if the imagery and the rich content of the rock-carving material has repressed interpretations rather than inspired them. The rock-carvings are in some respects ascribed great potential and significance, but this fact also makes it more hazardous to create comprehensive interpretations. Perhaps there is a tendency among archaeologists to have exaggerated respect for the conceptions behind the rock-carving traditions. Rock-carvings should neither be more nor less difficult to study than other contemporaneous phenomena. Different kinds of traces may simply express alternative aspects of life and society. Nevertheless, there is a tendency to regard rock-carving interpretations as doubtful and less serious than interpretations in other fields. This may be a result of the earlier mentioned, often divided, scholarly relation to interpretation during the recent years: scholars have either held back reflections on meaning to a minimum and instead dealt with statistics and descriptions, or devoted themselves to extensive interpretations without apparent connection to studies of the rock-carving material.

When it comes to rock-carvings, it is a tug-of-war between concentrating on the particular and yet viewing the general picture. It is hard to strike a balance between the two. During the first half of the $20^{\text {th }}$ century it was common to pick out separate images or scenes from a context, in order to date them and to explain what they symbolise or depict. This line of interpretation has justly been criticised (e.g. Kjellén \& Hyenstrand 1977:8; Bertilsson 1987:18; Malmer 1989a:91ff) but is still applied from time to time. To avoid this trap many scholars instead became busy with documentation and chronology to pre- pare the way for forthcoming interpretation. The problem is that when the basic material is finally presented, there is rarely any strength left for creative interpretations. Also in this respect the approach to rock-carvings differs from that of other ancient remains. Few people would probably argue that there is a need to register and keep accounts of the whole material of heaps of fire-cracked stone or graves in order to comment on a single example. On the other hand, it may be an advantage to have general knowledge when making serious attempts at interpretation. Rock-carvings are indeed hard to tear loose from their context, and the isolated interpretations are often vague. This impression is strengthened by the fact that attention is usually given to the spectacular and extraordinary images, at the expense of more common symbols and compositions. The most obvious example is the comparatively few lines that are devoted to the cupmarks in the studies, while the symbolism of special pictorial scenes can be treated page up and page down. Although the cupmarks sometimes are described as a key to general rockcarving meaning, there has been little interest in studying their significance. The only comprehensive monography on the subject was written by Oscar Lidén in the 1930s (Lidén 1938). Cupmarks frequently occur outside the figural rock-carving contexts, in concentrations or separately, often together with other ancient remains such as heaps of fire-cracked stone and cairns. They are often found on the upper, horizontal part of blocks of stone, instead of on open rock surfaces (fig. 9). Probably the cupmarks have a slightly different significance than the mixed rockcarvings, and may be well suited to bridge the gap between the lonesome, sailing, rockcarving expert and the scholar who has ambitions to acquire profound knowledge about the Bronze Age society but until now has left the mysterious rock-carvings outside the synthesis. 


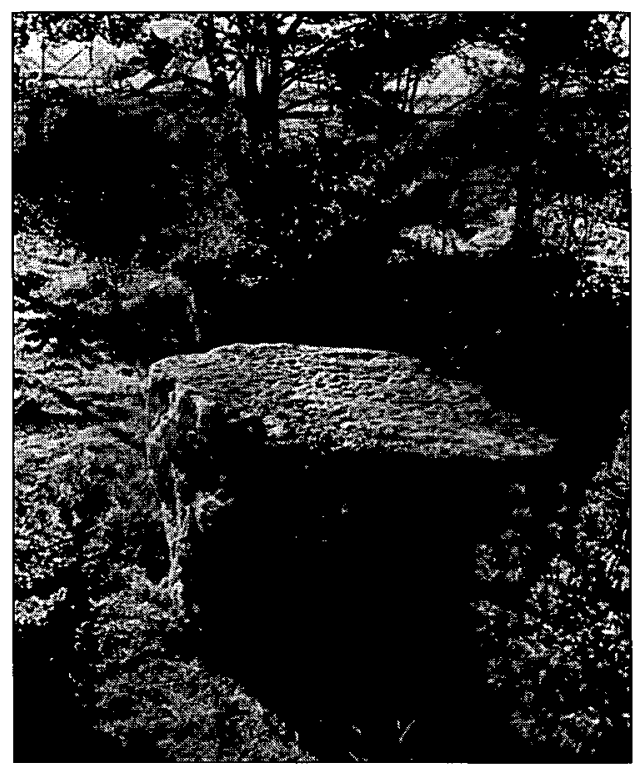

Fig. 9. Boulder with about 80 cupmarks on the top surface, resembling an altar, from Brillinge, Vaksala parish in Uppland (photo: Sören Hallgren 1972, from Kjellén 1976:179).

\section{VISIONS OF THE FUTURE}

\section{Towards interpretative dialogues}

I am well aware that I probably have not done justice to separate scholars, whether mentioned or forgotten, or the field of rockcarving studies in my analysis. Maybe the presented picture is too negative and discouraging. In the future my work will also be criticised, and maybe I will feel misunderstood or that my efforts are not appreciated. But that is quite all right; the interplay between questioning earlier results, creating new ones to question, constructing an alternative picture, and so on, is in fact some of the meaning of research. The only way to proceed, and to create deeper understanding of the people that made and used the rockcarving places, is to carry the discussion further. That means we have to participate in dialogues, not only produce one isolated text after another.
Towards a diversity in meaning

As a counter-reaction against the large-scale power and status perspective, rock-carving interest is once again focused on ritual aspects. I believe that consideration of the implications of religion, cosmology and mythology is necessary in order to approach rock-carving meaning, but that does not have to exclude studies of more profane signification. The important issues are still how, why, and for whom the rock-carvings were created. That brings us back to the questions posed by Einar Kjellén and Åke Hyenstrand more than twenty years ago (Kjellén \& Hyenstrand 1977), but where do we find the answers?

To me it seems obvious that the rockcarvings are not depictions of everyday life, or even disparate scenes of occurring events. On the contrary, the setting is limited and framed within strict boundaries. Regardless of whether the images are interpreted in terms of worship of deities, mythical expressions, objects in ritual acts or symbolic signs with transitional function, the world of images is restricted to a few selected spheres. Of course, the representations have significance for the interpretation of a society, even if it is a godly world that is reproduced on the rock (Burström 1999a), but it is important to discuss what aspects of life are rendered and why major ingredients are missing. Not every society has rock-carvings, and the rockcarvings are not evenly spread throughout a common cultural area. There are certainly other representations of Bronze Age societies that are worth studying. In the rock-carving perspective, the aggressive warlike dimension has tended to dominate, although there are other ancient remains that tell of a different way of life. This can be compared to the picture of the barbaric, and warfaring Viking, when most of the people during the Scandinavian Viking Age were in fact peasants. We must bear in mind that there are differences between an ideology, which at least in retrospect can be interpreted as 
the exposed identity of a society, and everyday conditions for different people. Therefore there is a need to bridge the gap between analyses of different materials. I believe that such contextual studies have already begun to transform the conception of rock-carving meanings.

The interpretative line with increasing focus on ritual action, and the elements participating in transitional acts, has also been enriched by inspiration from folkloristic beliefs and the southern African San rockpaintings (e.g. Lewis-Williams 1995). Several scholars have recently discussed the animated rock and/or the importance of the rock surface as a medium for rock-carving meanings (e.g. Kaliff 1997; Hauptman Wahlgren 1998; Hedengran \& Janzon 1999; L. Larsson 1999). In addition, we have a lot to learn from David Lewis-Williams' reflections on the limitations of his own and others' work concerning the San or Bushman rockpaintings. Although we have to be cautious when importing a completely disconnected context, the polysemic symbols of Bushman art are useful to keep in mind. For instance, it appears that the most commonly depicted animal, the eland, is associated with boys' first-kill observances, as well as with puberty rituals for girls, marriage rites, and the shamanistic healing dance (Lewis-Williams 1981, 1995). This is indeed a wider spectrum of complex meanings than we usually allow in the interpretations of Swedish rockcarvings.

Sometimes it is insinuated that rockcarvings are less interesting because they can be interpreted in almost any direction preferred (e.g. L. Larsson 1999:151); but perhaps the pluralistic signification is in fact part of the intention, and consequently one of the main purposes of rock-carvings. Besides, to me it is more remarkable that scholars with completely different approaches, methods and arguments can end up with similar interpretations. Or that it appears too easy to make the same mistakes as the ones you criticised earlier scholars for. Consider also that the interpretations often joins one side, or reflect the opposite opinion, instead of breaking ground for new fields of understanding. Obviously an agenda, set decades ago, is still governing the discourse, and whether you agree with previous interpretations or not, you are still caught within the existing framework of the field. Unfortunately the problem seems to be that our imaginations are too limited to do the rock-carvings justice, rather than being too fanciful.

Probably many of us would agree that the rock-carvings had significance within the tradition they were created. Consequently they should have much to tell us about the society. If the rock-carvings do express a cosmology, how can we expect to gain knowledge about the rest of Stone or Bronze Age society if the rock-carvings are not allowed greater interpretative potential? By becoming aware of the ritual aspects of everyday life, we can create different understandings of the rock-carvings as well as other contemporaneous phenomena. The carved symbols probably express substantial conceptions and beliefs that in various ways may also be inherent in other spheres.

There is a need to realise that different cosmological systems also encompass different mentalities. Most likely the Stone and Bronze Age mentality is very unlike our own. It is a daring but necessary insight to recognise prehistory as something foreign, further away from us than any living people in the world (see Burström 1999b, with references). This understanding does not have to be a disadvantage; it can also help us, as strangers, to recognise phenomena that are difficult to discern in our own cultural context. Further knowledge of rock-carving meaning is not a hopeless task at all, provided that some diversity in meaning is allowed, and that the fundamental question of why the carvings appeared and disappeared only in chosen areas, is seriously considered. As Jarl Nordbladh puts it: “... a wise research attitude 
would be not to ask about the meaning of rock art but rather to extract meanings from rock art" (Nordbladh 1999:19).

\section{Towards an understanding of rock-carving dynamics}

Another crucial point is to remember the dynamics of each rock-carving place. We tend to perceive a site as a jumble of images, but seldom consider that what appears on the rock is actually the last stage of a tradition, at the point when it was abandoned. When the tradition was at the height of its importance, the carved surface probably looked quite different. The use of rock-carvings stayed alive for hundreds of years, and it would be surprising if there were no major changes in the tradition during this time. Therefore it is important to allow some room for inconsistencies and arbitrariness in the understanding of the phenomenon. Despite the dating problems, the time dimension can contribute, not to more detailed chronological systems, but to the meaning-content of our interpretations.

It is about time that rock-carving traditions are conceived of in terms of actions. We can not stay content with the brief mention of rock-carvings as an abstract ritual phenomenon. What kinds of rituals were involved, and why were rock images needed in those contexts? Surely there is nothing outside the specific cultural and religious context that necessitates rock-carvings for the performance of transition rites, worship of ancestors, fertility cult, manifestation of status, hunting magic or any other purpose proposed. By studying the act of carving, some understanding for the medium as such can be attained. There are already many suggestions regarding the meaning of the images. It is high time for scholars to interpret also

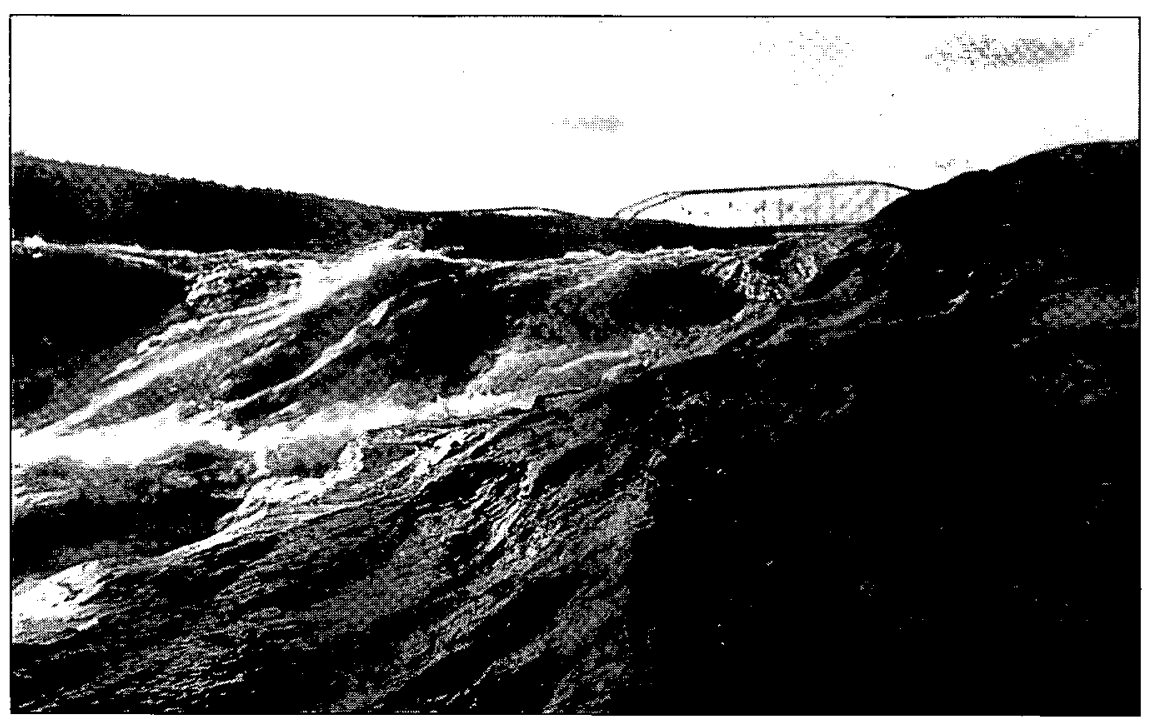

Fig. 10. What meanings are inherent in the dramatic landscape of the Nämforsen rockcarvings? Is there significance in the shore-line position of the carved rock, and of the turbulent waters that constantly douse the images? The act of carving on the slippery rock must have been a risky undertaking. Maybe the dangerous edge between rock and water is one of the qualities that made this a liminal place suitable for carvings. But why were the carved images needed? An important task for future research is to reflect upon the meaning of the carving act, and not just the meaning of the images. Photo: N. Azelius 1944, ATA. 
the meaning of the carving act (fig. 10).

Some reflections on what kind of expression rock-carvings represent, are also needed. In contrast to what has sometimes been suggested, I do not consider the rock-carvings to be monumental manifestations. The sites are difficult to distinguish from a distance, and the images are often almost impossible to discern unless they are newly carved, or painted. The images can not simply be messages for people passing through, since you have to know of the place to notice them. The rock-carvings do, of course, communicate to those who understand their meaning. But perhaps there is something crucial in the choice of medium and expression. It can not be overlooked that there are possibilities to activate the images on suitable occasions, either by re-carving an existing line or by adding a new figure. This would imply that only those parts of the carving surface that had relevance for the ritual emerged, and that the meaning of the place was in constant change between different rituals, and between the performance of an act and the time until the next ceremony.

In addition to this problem complex, we have to depart from the rock-carving site itself and ask why this place was chosen and not another nearby. Do the rock-carving places have special prerequisites for becoming ritual sites? Are there certain phenomena of nature in the landscape, liminal places and areas that called for control or transformation through the rock images? Or were there other reasons for the localisation of the carvings? In my opinion, these kinds of questions can only be understood if specified analyses are combined within a broader context of studies of landscape and other contemporaneous ancient remains, where the significance of the rituals and the religious expressions permeate everyday life as well as the ceremonial acts.

\section{Towards the dissolution of rock-carving interpretations}

I believe that the rock-art field of archaeology is slowly beginning to dissolve, not to disintegrate but to become integrated into wider social, ideological and religious discourses. In the future there will be greater differences among scholars with disconnected views on society than among those who have chosen different materials as points of departure. An important task for the archaeologists is to create significant interpretations with theoretical awareness that has basis in the studied material context, and not just another general model.

Perhaps the above reflections do not seem like visions of the future. In many respects they appear to be a series of self-evident comments, yet nevertheless I find them applicable. That of course says something about myself, but also to a large degree about the earlier, scholarly, rock-carving traditions.

\section{English revised by Laura Wrang.}

\section{ABBREVIATIONS}

ATA Antikvarisk-Topografiska Arkivet, Stockholm. (The Antiquarian Topographical Archive, Stockholm.)

KVHAA Kungliga Vitterhets Historie och Antikvitets Akademien. (The Royal Academy of Letters, History and Antiquiteis.) 


\section{REFERENCES}

Almgren, B. 1960. Hällristningar och bronsåldersdräkt. TOR 6. Uppsala. Pp. 19-50.

- 1962. Den osynliga gudomen. In: Proxima Thule. Hyllningsskrift till H. M. Konungen. Stockholm. Pp. 53-71.

Almgren, O. 1913. Tanums härads hällristningar från bronsåldern. In: Bidrag till kännedom om Göteborgs och Bohusläns fornminnen och historia. Band 8. Göteborg. Pp. 473-575.

- 1927. Hällristningar och kultbruk. KVHAA:s handlingar 35. Stockholm.

Althin, C.-A. 1945a. Studien zu den bronzezeitlichen Felszeichnungen von Skaine I \& II. Lund.

- 1945b. "Älvornas kvarnar" och "fruktbarhetsgudens fotspår". Folkkultur. Lund.

Andersson, T. 1997. Arkeologisk rapport 2 frăn Vitlyckemuséet. Högsbln i Tisselskogs socken. Tanumshede.

Artelius, T. 1996. Långfärd och återkomst - skeppet i bronsålderns gravar. RÄ̈. Arkeologiska undersökningar. Skrifter No 17. Kungsbacka.

Baltzer, L. 1881-1908. Glyphes de Rochers du Bohuslän 1-2. Göteborg.

Baudou, E. 1977. Den förhistoriska făngstkulturen i Västernorrland. In: Baudou, E. \& Selinge K.-G. (Eds), Västernorrlands förhistoria. Västernorrlands läns landsting. Pp. 15-52.

- 1993. Hällristningarna vid Nämforsen datering och kulturmiljö. In: Forsberg, L. \& Larsson, T. B. (Eds). Ekonomi och näringsformer $i$ nordisk bronsålder: Rapport från det 6:e nordiska bronsålderssymposiet, Nämforsen 1990. Studia Archaeologica Universitatis Umensis 3. Umeå. Pp. 247-261 .

Bellander, E. 1938. Bălrösen-offerrösen. In: Kulturhistoriska studier tillägnade Nils Åberg 24/7 1938. Stockholm. Pp. 91-l00.

Bengtsson, L. (Ed). 1997. Arkeologisk rapport 3 från Vitlyckemuséet. Hällristningar från Askums socken, Bohuslän. Tanumshede.

- 1998. Arkeologisk rapport 4 från Vitlycke museum. Hällristningar från Askums socken, Bohuslän, del 2. Tanumshede.

Bengtsson, L. 1999. Manligt - kvinnligt. Kring dolda strukturer på hällristningar i Bohuslän. In: Olausson, M. (Ed). Spiralens öga. Tjugo artiklar kring aktuell bronsåldersforskning. Riksantikvarieämbetet. Avdelningen för arkeologiska undersökningar. Skrifter nr 25.
Stockholm. Pp. 309-320.

Bertilsson, U. 1985. Nyregistrering av hällbilder i Bohuslän 1982-83. In: Arkeologi i Sverige 1982-1983. Riksantikvarieämbetet. Stockholm. Pp. 207-221.

- 1987. The Rock Carvings of Northern Bohuslän. Spatial Structures and Social Symbols. Stockholm Studies in Archaeology 7. Stockholm. Diss.

- 1989a. Hällristningar och bygden. In: Janson, S., Lundberg, E. B. \& Bertilsson, U. (Eds). Hällristningar och hälmålningar $i$ Sverige. Forum. Pp. 29-42

- 1989b. Rock-carvings, ideology and society in the Bronze Age of western Sweden. In: Nordström, H. A. \& Knape, A. (Eds). Bronze Age Studies. Transactions of the British-Scandinavian Colloquium in Stockholm, May 10 11, 1985. The Museum of National Antiquities. Studies 6. Stockholm. Pp. 101-109.

- 1995. Rock art, recent research and religion. In: Helskog, K. \& Olsen, B. (Eds). Perceiving Rock Art: Social and Political Perspectives. ACRA: The Alta Conference on Rock Art. Instituttet for sammenlignende kulturforskning. Serie B: Skrifter XCII. Novus forlag. Oslo. Pp. 207-214.

- 1999. Rock art - divine messages or socio realistic representations? In: Gustafsson, A. \& Karlsson, H. (Eds). Glyfer och arkeologiska rum - en vänbok till Jarl Nordbladh. Gotarc Series A. Vol 3. Göteborg. Pp. 743-750.

Bolin, H. 1999. Animal Magic. The Mythological Significance of Elks, Boats and Humans in North Swedish Rock Art. In: Bolin, H. Kulturlandskapets korsvägar: Mellersta Norrland under de två sista årtusendena $f$. Kr. Stockholm Studies in Archaeology 19. Stockholm. Pp. 140-163. Diss.

Bradley, R. 1997a. Death by Water: boats and footprints in the rock art of western Sweden. Oxford Journal of Archaeology 16. Pp. 1624.

- 1997b. Rock Art and the Prehistory of Atlantic Europe. Signing the Land. Routledge. London. Brunius, C. G. 1868. Försök till förklaringar öfver Hälristningar med femton planscher. Lund.

Burenhult, G. 1973. The Rock Carvings of Götaland (excluding Gothenburg county, Bohuslän and Dalsland). Part II. Acta Archaeologica Lundensia. Series in $4^{\circ}$. $N^{\circ} 8$. Lund.

1980. Götalands hällristningar. Del I. Theses 
and Papers in North-European Archaeology 10. Stockholm. Diss.

Burström, M. 1999a. On earth as in heaven. Images of the divine as ideological messages in bronze age society. In: Gustafsson, A. \& Karlsson, H. (Eds). Glyfer och arkeologiska rum - en vänbok till Jarl Nordbladh. Gotarc Series A. Vol 3. Göteborg. Pp. 625-631.

- 1999b. Cultural Diversity in the Home Ground. How Archaeology Can Make the World a Better Place. Current Swedish Archaeology; Vol. 7. Pp. 21-26.

Chippindale, C \& Taçon, P. S. C. (Eds). 1998. The Archaeology of Rock-Art. Cambridge University Press.

Dowson, T. A. \& Lewis-Williams, J. D. (Eds). 1994. Contested images: diversity in southern African rock art research. Witwatersrand University Press. Johannesburg.

Ekholm, G. 1916. De skandinaviska hällristningarna och deras betydelse. Ymer: Pp. 275-308.

- 1921. Studier i Upplands bebyggelsehistoria II. Bronsåldern. Uppsala.

- 1922a. Hällristningsproblemet. Ett genmäle. Fornvännen. Pp. 213-229.

- 1922b. Om hällristningarnas kronologi och betydelse. Slutord till antikvarien Schnittger. Fornvännen. Pp. 239-259.

Forsberg, L. 1993. En kronologisk analys av ristningarna vid Nämforsen. In: Forsberg, L. \& Larsson, T. B. (Eds). Ekonomi och näringsformer $i$ nordisk bronsålder: Rapport från det 6:e nordiska bronsålderssymposiet, Nämforsen 1990. Studia Archaeologica Universitatis Umensis 3. Umeå. Pp. 195-246.

Goldhahn, J. 1999. Sagaholm - hällristningar och gravritual. Studia Universitatis Umensis 11. Jönköpings Läns Museums Arkeologiska Rapportserie 41.

Görman, M. 1987. Nordiskt och keltiskt. Sydskandinavisk religion under yngre bronsålder och keltisk järnålder. Lund. Diss.

Hallström, G. 1960. Monumental art of northern Sweden from the Stone Age. Nämforsen and other localities. Stockholm.

Hauptman Wahlgren, K. 1998. Encultured Rocks. Encounter with a Ritual World of the Bronze Age. Current Swedish Archaeology, Vol. 6. Stockholm. Pp. 85-97.

Hedengran, I. 1989. Omsorg vid Dragby och omsorg vid Fiskeby. En frăga om skillnad i social struktur och organisation eller i identifikation av omsorg? In: Damell, D. et al. (Eds). Mänsklighet genom millennier: En vänbok till Åke Hyenstrand. Pp. 85-91.

- 1990. Skeppet i kretsen. Kring en symbolstruktur i Mälardalens förhistoria. Fornvännen. Pp. 229-238.

- 1993. Att synliggöra människor, figurer eller gestalter? Kring hällristningsforskningens förutsättningar. In: Forsberg, L. \& Larsson, T. B. (Eds). Ekonomi och näringsformer i nordisk bronsålder: Rapport från det 6:e nordiska bronsålderssymposiet, Nämforsen 1990. Studia Archaeologica Universitatis Umensis 3. Umeå. Pp. 177-193.

- 1995. The ship wrecked and their rescuer. Reflections on ship symbolism in Southern Scandinavian rock art. In: Crumlin-Pedersen, O. \& Munch Thye, B. (Eds). The Ship as Symbol in Prehistoric and Medieval Scandinavia. Publications from the National Museum. Studies in Archaeology and History 1. Kobenhavn. Pp. 76-85.

Hedengran, I. \& Janzon, G. O. 1999. De stenbundna skeppen. Om skeppsristningar och skeppsformade stensättningar i Tjust, nordöstra Småland. In: Gustafsson, A. \& Karlsson, H. (Eds). Glyfer och arkeologiska rum - en vänbok till Jarl Nordbladh. Gotare Series A. Vol 3. Göteborg. Pp. 375-400.

Helskog, K. 1988. Helleristningene i Alta. Spor etter ritualer og dagligliv i Finnmarks forhistorie. Alta Museum.

- 1995. Maleness and femaleness in the sky and the underworld - and in between. In: Helskog, K. \& Olsen, B. (Eds). Perceiving Rock Art: Social and Political Perspectives. ACRA: The Alta Conference on Rock Art. Instituttet for sammenlignende kulturforskning. Serie B: Skrifter XCII. Novus forlag. Oslo. Pp. 247262.

- 1999. The Shore Connection. Cognitive Landscape and Communication with Rock Carvings in Northernmost Europe. Norwegian Archaeological Review. Vol. 32. No. 2. Pp. 73-94.

Helskog, K. \& Olsen, B. (Eds). 1995. Perceiving Rock Art: Social and Political Perspectives. ACRA: The Alta Conference on Rock Art. Instituttet for sammenlignende kulturforskning. Serie B: Skrifter XCII. Novus forlag. Oslo.

Hildebrand, B. E. 1869. Till hvilken tid och hvilket 
folk böra de Svenska Hällristningarne hänföras? Antiquarisk Tidskrift for Sverige II. Stockholm. Pp. 417-432.

Holmberg, A. E. 1848. Skandinaviens Hällristningar, arkeologisk afhandling. Stockholm.

Hood, B. C. 1988. Sacred pictures, sacred rocks: ideological and social space in North Norwegian Stone Age. Norwegian Archaeological Review: Vol 21. Pp. 65-84.

Högberg, T, 1995. Arkeologisk rapport 1 från Vitlyckemuséet. Hällristningar firàn Litsleby, Tegneby \& Bro i Tanums socken. Uddevalla.

- 1997. Hällbilder på Kalleby. Strömstad.

Jankavs, P. 1996. Flyhovs hällristningar. Nya bilder i ett gammalt fynd. Bygga och Bo. 1000 àr $i$ Västergötland. Västergötlands Fornminnesförenings Tidskrift 1995-1996. Pp. 224-229.

- 1998. Hällristningen vid Blomberg. Västergötlands Fornminnesforenings Tidskrift 19971998. Pp. 116-119.

- 1999. Rapsodi över hällbilder i Skaraborg med impromptu för skålgropar och fotsulor. In: Gustafsson, A. \& Karlsson, H. (Eds). Glyfer och arkeologiska rum - en vänbok till Jarl Nordbladh. Gotarc Series A. Vol 3. Göteborg. Pp. 411-439.

Janson, S., Lundberg, E. B. \& Bertilsson, U. (Eds). 1989. Hällristningar och hällmålningar $i$ Sverige. Forum.

Jensen, R. 1989. Härjedalen och Jämtland. In: Janson, S., Lundberg, E. B. \& Bertilsson, U. (Eds). Hällristningar och hällmålningar $i$ Sverige. Forum. Pp. 198-212.

Johansen, Ø. 1979. New Results in the Investigation of the Bronze Age Rock Carvings. Norwegian Archaeological Review. Vol. 12. Oslo. Pp. 108-114.

- 1980. Utgravninger ved ristningsfelt $i \emptyset_{\text {stfold. }}$ Varia 1. Universitetets Oldsaksamling. Oslo.

Kaliff, A. 1997. Grav och kultplats. Eskatologiska föreställningar under yngre bronsålder och äldre järnålder $i$ Östergötland. Aun 24. Uppsala. Diss.

Kaul, F. 1995. Ships on Bronzes. In: CrumlinPedersen, O. \& Munch Thye, B. (Eds). The Ship as Symbol in Prehistoric and Medieval Scandinavia. Publications from the National Museum. Studies in Archaeology and History 1. København. Pp. 59-70.

Kjellén, E. 1976. Upplands hällristningar: The Rock Carvings of Uppland. Sweden. Med bidrag av Einarstam, B., Hallgren, S. \& Hyenstrand, $\AA$. (Eds). KVHAA. Stockholm.

Kjellén, E. \& Hyenstrand, A. 1977. Hällitistningar och bronsålderssamhälle i sydvästra Uppland. Upplands fornminnesförenings tidskrift 49. Uppsala.

Larsson, L. 1999. Rock of divergent dimensions. In: Gustafsson, A. \& Karlsson, H. (Eds). Glyfer och arkeologiska rum - en vänbok till Jarl Nordbladh. Gotarc Series A. Vol 3. Göteborg. Pp. 151-160.

Larsson, T. B. 1989. Bronze! Power and wealth in Early Bronze Age Scania. In: Nordström, H. A. \& Knape, A. (Eds). Bronze Age Studies. Transactions of the British-Scandinavian Colloquium in Stockholm, May 10-11, 1985. The Museum of National Antiquities. Studies 6. Stockholm. Pp. 25-44.

- 1993. Vistad. Kring en befäst gård $i$ Östergötland och östersjökontakter under yngre bronsålder: Studia Archaeologica Universitatis Umensis 4. Umeå.

- 1997. Materiell kultur och religiösa symboler: Mesopotamien, Anatolien och Skandinavien under det andra förkristna årtusendet. Arkeologiska Studier vid Umeå Universitet 4. Umeå.

- 1999. Symbols in a European Bronze Age Cosmology. In: Orrling, C. (Ed). Communication in Bronze Age Europe. Transactions of the Bronze Age Symposium in Tanumstrand, Bohuslän, Sweden, September 7-10, 1995. The Museum of National Antiquities. Studies 9. Stockholm. Pp. 9-16.

Larsson, T. B. \& Broström, S.-G. 1999. Nyupptäckta hällristningar vid Laxforsen, Nordmalings socken, Västerbottens län - en kort notis. Fornvännen. Pp. 187-190.

Lewis-Williams, J. D. 1981. Believing and seeing: symbolic meanings in southern San rock paintings. Academic Press. London.

1995. Perspectives and traditions in southern African rock art research. In: Helskog, K. \& Olsen, B. (Eds). Perceiving Rock Art: Social and Political Perspectives. ACRA: The Alta Conference on Rock Art. Instituttet for sammenlignende kulturforskning. Serie B: Skrifter XCII. Novus forlag. Oslo. Pp. 6586.

Lidén, O. 1938. Hällgröpningsstudier: I anslutning till nya sydsvenska fynd. Lund.

Lindqvist, C. 1983. Arktiska hällristningsbåtar spekulationer om kulturellt utbyte via kust- 
och inlandsvattenvägar i Nordfennoskandia. Meddelanden frản Marinarkeologiska Sällskapet. No 1. Pp. 2-14.

- 1994. Fångstfolkets bilder. En studie av de nordfennoskandiska kustanknutna jägarhällristningarna. Theses and Papers in Archaeology. New Series A. Nr 5. Stockholm. Diss.

Lundström, P. 1965. Gravfälten vid Fiskeby $i$ Norrköping II. Fornlämningar och fynd. KVHAA. Stockholm.

- 1970. Gravfälten vid Fiskeby i Norrköping I. Studier kring ett totalundersökt komplex. KVHAA. Stockholm.

Malmer, M. P. 1971. Bronsristningar. KUML 1970. Århus. Pp. 189-210.

- 1981. A Chorological Study of North European Rock Art. Antikvariska serien 32. KVHAA. Stockholm.

- 1989a. Principles of non-mythological explanation of North-European Bronze Age rock art. In: Nordström, H. A. \& Knape, A. (Eds). Bronze Age Studies. Transactions of the British-Scandinavian Colloquium in Stockholm, May 10-11, 1985. The Museum of National Antiquities. Studies 6. Stockholm. Pp. 91-99.

- 1989b. Bergkonstens mening och innehåll. In: Janson, S., Lundberg, E. B. \& Bertilsson, U. (Eds). Hällristningar och hällmålningar $i$ Sverige. Forum. Pp. 9-28.

- 1993. Rock Art and Writing. In: Arwidsson, G. et al. (Eds). Sources and Resources. Studies in Honour of Birgit Arrhenius. PACT 38. Pp. $551-560$.

Mandt, G. 1982. Review of: Göran Burenhult, "Götalands hällristningar, Del I", Theses and papers in North-European Archaeology 10, Stockholm, 1980, and "The Rock Carvings of Götaland, Part II", Acta Archaeologica Lundensia in series $4^{\circ}, 1973$, Lund. Fornvännen. Pp. 261-264.

- 1986. Searching for Female Deities in the Religious Manifestations of the Scandinavian Bronze Age. In: Steinsland G. (Ed). Words and Objects. Norwegian University Press. Oslo. Pp. 111-127.

- 1987. Female symbolism in rock art. In: Bertelsen, R., Lillehammer, A. \& Næss, J-R. (Eds). Were they all men? AmS-Varia 17. Stavanger.

- 1995. Alternative analogies in rock art interpretations: the West Norwegian case. In: Helskog, K. \& Olsen, B. (Eds). Perceiving
Rock Art: Social and Political Perspectives. ACRA: The Alta Conference on Rock Art. Instituttet for sammenlignende kulturforskning. Serie B: Skrifter XCII. Novus forlag. Oslo. Pp. 263-291.

Nordbladh, J. 1980. Glyfer och rum. Kring hällristningarna i Kville. Göteborg. Diss.

- 1981. Knowledge and Information in Swedish Petroglyph Documentation. In: Moberg, C.A. Similar finds? Similar interpretations? University of Gothenburg. Department of Archaeology. Pp. G1-79.

- 1987. Bird, fish or somewhere in between? The case of the rock paintings of the Swedish west coast. In: Burenhult, G., Carlsson, A., Hyenstrand, A. \& Sjøvold, T. (Eds). Theoretical Approaches to Artefacts, Settlement and Socien: Studies in honour of Mats P. Malmer: British Archaeological Reports. International Series. Part II. Pp. 305-320.

- 1989. Armour and fighting in the South Scandinavian Bronze Age, especially in views of rock art representations. In: Larsson, T. B. \& Lundmark, H. (Eds). Approaches to Swedish Prehistory. British Archaeological Reports. International Series 500. Pp. 323-333.

- 1995. The history of Scandinavian rock art research as a corpus of knowledge and practice. In: Helskog, K. \& Olsen, B. (Eds). Perceiving Rock Art: Social and Political Perspectives. ACRA: The Alta Conference on Rock Art. Instituttet for sammenlignende kulturforskning. Serie B: Skrifter XCII. Novus forlag. Oslo. Pp. 23-34.

- 1999. The Interaction of and with Rock Images. In: Orrling, C. (Ed). Communication in Bronze Age Europe. Transactions of the Bronze Age Symposium in Tanumstrand, Bohuslän, Sweden, September 7-10, 1995. The Museum of National Antiquities. Studies 9. Stockholm. Pp. 17-22.

Nordbladh, J. \& Rosvall, J. (Eds). 1971. Rockcarvings. Kville hundred, Svenneby parish (county of Bohuslän). Documentation: Åke Fredsjö. Studies in North European Archaeology 7. Göteborg.

- 1975. Rock-carvings. Kville hundred. Bottna parish (county of Bohuslän). Documentation: Åke Fredsjö. Studies in North European Archaeology 13. Göteborg.

- 1981. Rock-carvings. Kville hundred, Kville parish (county of Bohuslän). Part $I \& 2$. 
Documentation: Åke Fredsjö. Studies in North European Archaeology 14/15. Göteborg.

Nordén, A. 1922. Felsbilder der Prowinz Ostgotland.

- 1925. Östergötlands bronsålder. Linköping. Diss.

Nordenskjöld, C. F. 1870-1873, 1876, 1877 \& 1880. Östergötlands minnesmärken. Unpublished reports. ATA. Stockholm.

- 1933-1934. Östergötlands minnesmärken. Unpublished reports. ATA. Stockholm.

Nordström, P. 1995. Arkeologiska undersökningar invid hällristningar. Analys av 16 utgrävningar invid hällristningar $i$ Sverige och Norge. Seminar paper. Department of Archaeology, Stockholm University.

Pettersson, J. 1982. Hällristningar på Tjörn. Del II. Malung.

- 1984. Mätvärden på hällristningen i Järrestad, Skåne - till frågan om hällristningsforskningens metodik. Fornvännen. Pp. 197-199.

Pettersson, J. \& Kristiansson, G. 1977. Hällristningar på Tjörn. Malung.

Ramquist, P. H., Forsberg, L. \& Backe, M. 1985. .... and here was an elk too... A preliminary report of new petroglyphs at Stornorrfors, Ume river. In: In Honorem Evert Baudou. Archaeology and Environment 4. Umeå. Pp. 313-337.

Randsborg, K. 1993. Kivik. Archaeology \& Iconography. Acta Archaeologica. Vol. 64(1). København.

Rex Svensson, K. 1982. Hällristningar i Älvsborgs län. En inventering av samtliga kända hällristningar $i$ Dalsland och Göta Älvdalen. Stiftelsen Älvsborgs Länsmuseum. Uddevalla.

Schnittger, B. 1922a. En hällristning vid BergaTuna i Södermanland. Fornvännen. Pp. 77112.

- 1922b. Hällristningarnas kronologi och betydelse. Ett genmäle till docent Ekholm. Fornvännen. Pp. 229-239.

Selinge, K. G. 1985. Om dokumentation av hällristningar. Metodiska synpunkter med östgötska exempel. Fornvännen. Pp. 97-120.

- 1989. Östergötland. In: Janson, S., Lundberg, E. B. \& Bertilsson, U. (Eds). Hällristningar och hällmålningar i Sverige. Forum. Pp. 147165.

Sognnes, K. 1994. Ritual landscapes: toward a reinterpretation of the Stone Age rock art in
Trøndelag, Norway. Norwegian Archaeological Review: Vol 27. Pp. 29-50.

Tanums Hällristningsmuseum Underslös. 1996. Dokumentation och registrering av hällristningar i Tanum. No 1. Aspeberget. Milstreu, G. \& Prøhl, H. (Eds). Tanumshede. Parallel title: Scandinavian Society for Prehistoric Art. Documentation and Registration of Rock Art No 1.

- 1999. Dokumentation och registrering av hällristningar i Tanum. No 2. Fossum med angränsande områden. Tanumshede. Parallel title: Scandinavian Society for Prehistoric Art. Documentation and Registration of Rock Art No 2.

Tilley, C. 1991. Material Culture and Text: the Art of Ambiguity. Routledge. London.

- 1999. Metaphor and Material Culture. Blackwell. Oxford.

Tilley, C. \& Thomas, J. 1993. The Axe and the Torso: Symbolic Structures in the Neolithic of Brittany. In: Tilley, C. (Ed). Interpretative Archaeology. Explorations in Anthropology. Berg Publishers. Oxford. Pp. 225-324.

Welinder, S. 1974. A study on the Scanian rock carvings by quantitative methods. Meddelanden frän Lunds Universitets Historiska Museum 1973-1974. Pp. 244-275.

Wennstedt Edvinger. B. 1993. Genus och djursymbolik. $O m$ den norrländska fängstkulturens organisation med avseende på kön. Arkeologiska studier vid Umeå Universitet 1 . Institutionen för arkeologi, Umeå universitet. Lic.

Widholm, D. 1998. Rösen, ristningar och riter: Acta Archaeologica Lundensia. Series Prima in $4^{\circ}$. $\mathrm{Nr} 23$. Lund. Diss.

Wigren, S., Broström, S.-G., Ihrestam, K. \& Eriksson, B. 1990. Hällristningarna $i$ Släbroparken, Nyköping. Arkeologisk undersökning och dokumentation. Länsstyrelsen i Södermanlands län informerar, nr 2. Kulturmiljöenheten. Nyköping.

Wihlborg, A. 1978. Sagaholm. A Bronze Age barrow with rock-carvings. Meddelanden frain Lunds Universitets Historiska Museum 19771978. New Series 2. Pp. 111-128.

Yates, T. 1993. Frameworks for an Archaeology of the Body. In: Tilley, C. (Ed). Interpretative Archaeology. Explorations in Anthropology. Berg Publishers. Oxford. Pp. 31-72. 